\title{
HRAD ZÍTKOV U CHOCNĚ VE SVĚTLE ARCHEOLOGICKÝCH NÁLEZŮ
}

\section{DAVID VÍCH}

\begin{abstract}
Abstrakt: V letech 2007-2011 proběhl pod vedením archeologa Regionálního muzea ve Vysokém Mýtě detektorový průzkum hradu Zitkov (Pardubický kraj, Česká republika) u Chocně zaměrený na povrchové vrstvy ohrožené zneuživáním detekčni techniky. Kolekce předmětů dokládá život na hradě zejména v pokročilém 14. a staršim úseku 15. století, kdy byl hrad mimo jiné dobýván. Stopově byly zachyceny i dosud neznámé aktivity ze 13. století.
\end{abstract}

Klíčová slova: vrcholný středověk-hrad-kovové předměty.

\section{The Zítkov castle, near Chocen̆ in the light of archaeological finds}

Abstract: The Zitkov castle (Pardubice Region, Czech Republic) near Chocen̆ was investigated by means of metal detection in 2007-2011. The research was led by the archaeologist of the Regional Museum in Vysoké Mýto and focused on surface layers endangered by the illicit use of the metal detecting technology. The collection of finds illustrates life in the castle, mainly in the later 14th century and the early 15th century when the castle was besieged. Traces of unknown activities from the 13th century were detected as well.

Key words: high Middle Ages - castle - metal objects.

\section{1 Úvod}

Poznávání vrcholně středověkých fortifikací v okolí Chocně patří k velmi obtížným úkolům. Příčinou je nesoulad ve výpovědích pramenů, kdy nedokážeme ztotožnit informace z pramenů písemných s relikty dochovanými do dnešních dnů. Zlepšit stav poznání hradů v okolí Chocně dnes mohou především nové poznatky k jednotlivým lokalitám získané archeologickým způsobem. Jednou z takových lokalit je i hrad Zítkov.

\section{Choceňsko ve vrcholném stř̌edověku}

První, ovšem bohužel velmi nejasná zmínka o hradu v Chocni se váže k samému závěru 13. století. Z listu Burcharda, arcibiskupa magdeburského, Heřmanovi, kaplanovi krále Václava II., se dozvídáme, že prý král chce stavět v Chocni hrad (Loserth 1896, 77-78 č. 87), když předtím roku 1292 postoupil toto území spolu s vesnicemi v okolí a dalším pozemkovým majetkem nově založenému klášteru na Zbraslavi (RBM IV, 745 č. 1888). O tom, zda Václav II. svůj záměr realizoval, však nevíme vůbec nic.

Na existenci hradu reálně ukazuje list Mikuláše z Potštejna lazebníkovi v městečku Kostelci nad Orlicí z roku 1330, v němž zmiňuje Hynka z Chocně (,Hinczici miles de Choczna“) považovaného za purkrabího na hradě tehdejšího majitele Chocně Mikuláše z Potštejna (Sedláček 1883, 248; Musil 1995, 36). O hradě v Chocni nedlouho poté píše i Karel IV., který ve svém životopise Vita Caroli k roku 1338 uvádí: „Estate eadem veniens prope Mutam fregi castrum Choczyn et alia quam plura castra domini de Potnsteyn, quia habui eodem tempore guerram cum eodem domino (...). ${ }^{\text {"1 }} \mathrm{V}$ průběhu 14. století došlo k rozdělení Chocně - jedna polovina připadla Lichtemburkům, kteří vlastnili panství litické, druhou polovinu měli v majetku pánové z Potštejna držící hrad Žampach. Zatímco v souvislosti s žampašskou částí Chocně se žádný hrad ani tvrz neuvádí, Ješek Pykna z Lichtemburka se k roku 1388 připomíná jako pán na Novém hradě a za Zikmunda Pykny z Lichtemburka je na počátku 15. století v Chocni zmíněna tvrz (Sedláček 1883, 249-251; Musil 1995, 36).

1 Podle https://www.phil.muni.cz/german/projekty/hmb/e-text/fr_VitaCaroli_cz.html, cit. 30. 4. 2018. „Téhož léta jsem přijel $k$ Vysokému Mýtu a zbořil jsem hrad Choceň a četné hrady pána z Potštejna, nebot’ jsem toho času vedl válku s tímto pánem (...).“ (česky podle Bláhová a kol. 1987, 38) 
Na základě výše uvedených zpráv bývá hrad (dnes označovaný podle novodobých majitelů pozemků jako Zítkov) ztotožňován s Novým hradem připomínaným k roku 1388 (Musil 1995, 37; Durdík 2000, 211, 629).

\section{Hrad Zítkov}

Ve vzdálenosti $1650 \mathrm{~m}$ západně od centra Chocně se na kopci nad Tichou Orlicí v nadmořské výšce okolo $330 \mathrm{~m}$ nachází zbytky hradu (obr. 1). Část kopce padla za obět' stavbě železniční trati Choceň - Hradec Králové, to se však naštěstí netýká hradu ani jeho bezprostředního okolí.

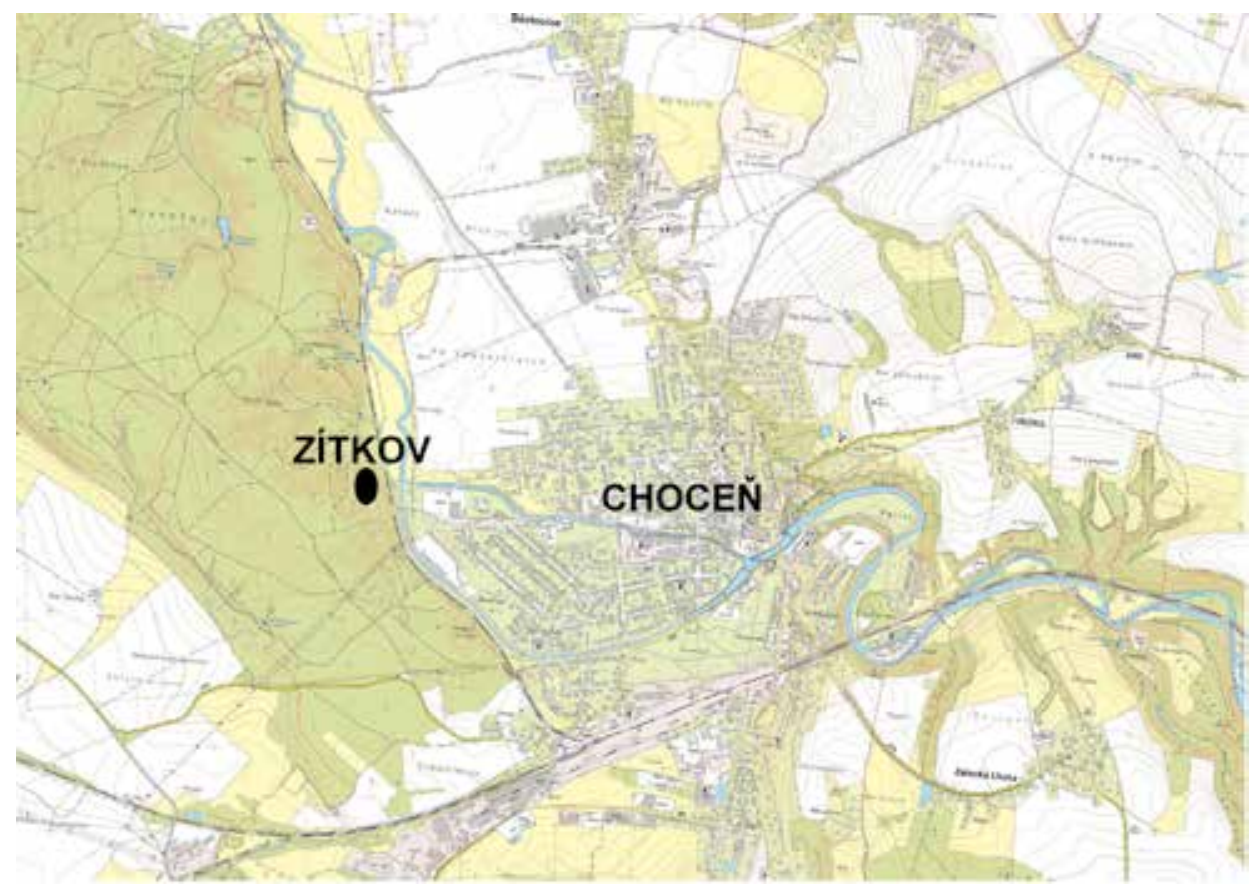

Obr. 1. Poloha lokality na mapovém výřezu.

Abb. 1. Lage der Fundstätte in einem Kartenausschnitt.

Hradní jádro tvoří pahorek ze západní strany vymezený svahem spadajícím k bezejmenné drobné vodoteči se dvěma plošinami zaříznutými do svahu. Severní svah pak chrání val a příkop, z jihu terén spadá $\mathrm{k}$ Tiché Orlici. Z jižní strany odděluje jádro od předhradí př́íkop. Více méně ploché hradní jádro člení dvě terénní deprese představující pozůstatky suterénu dvou staveb. Toto uspořádání patří k oblíbeným v pokročilém 14. století (Durdík 2000, 629). Ploché je rovněž i předhradí, poněkud členitější je pouze ve své východní části. Předhradí vymezuje vůči předpolí další prríkop s výraznou vyvýšeninou považovanou za zbytek věže chránící prrístup do hradu. Zde obvykle pozornost věnovaná hradu končí, nicméně ještě jižněji je v terénu patrný zbytek dalšího př́ikopu, přičemž v této části je návrší západním směrem propojeno s okolním terénem přístupovou šíjí (obr. 2). Původně jsme logicky předpokládali, že tento zbytek prŕíkopu vymezuje další předhradí a př́ístupová šíje byla uměle navršena při stavbě cesty, která po ní probíhá, a to někdy po zániku hradu. Množství stř̌edověkých nálezů (zejména hroty šípů) z povrchu přistupové šíje však dokazuje, že se jedná o původní terén. 


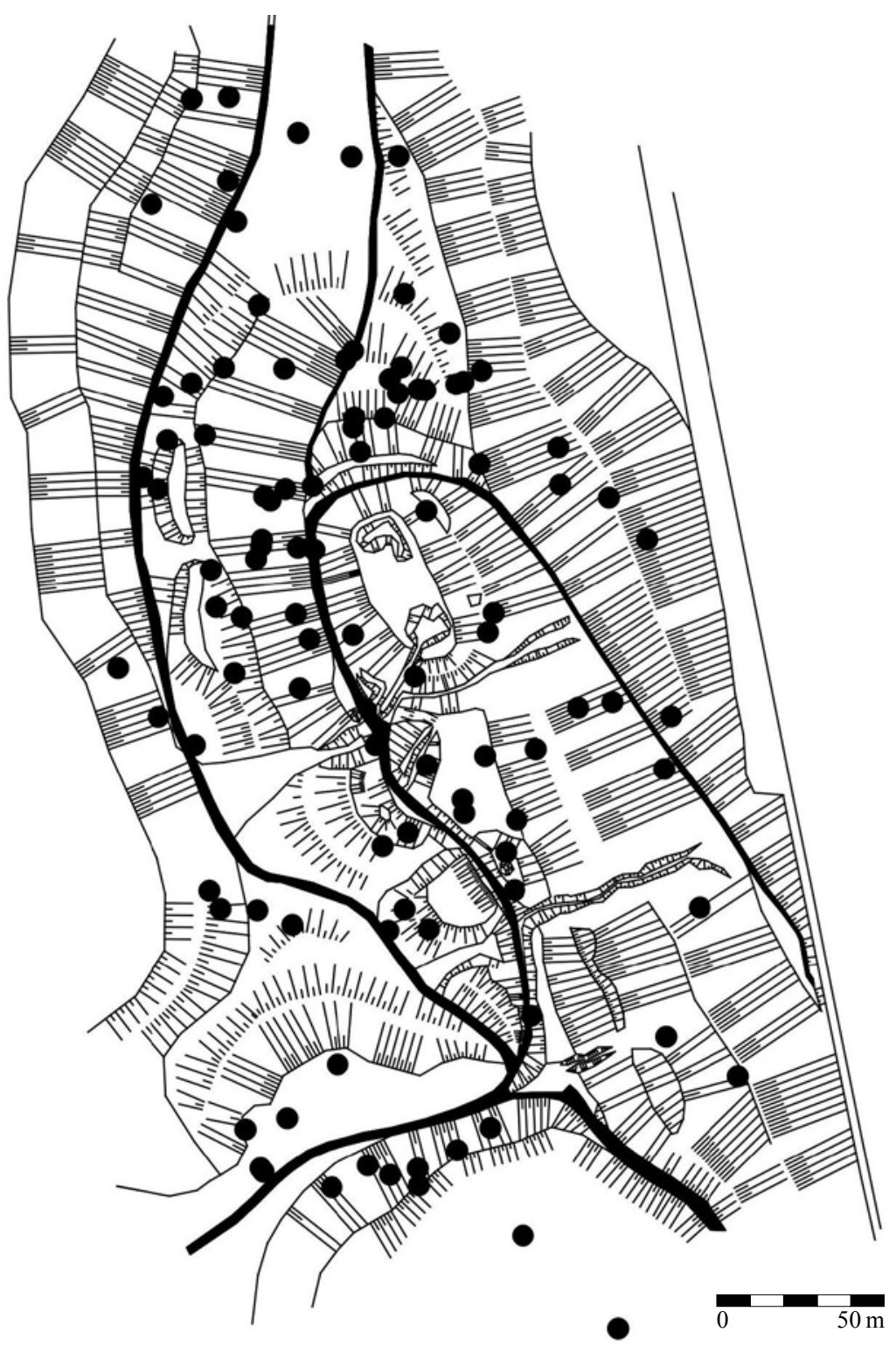

Obr. 2. Geodetický plán lokality s vynesením nálezů. Zaměření lokality Zeměměřičská kancelár̆ Kostelec nad Orlicí, vynesení nálezủ autor v programu Quantum GIS.

Abb. 2. Geodätische Planskizze mit eingezeichneten Funden. Vermessung der Fundstätte Büro für Landesvermessung in Kostelec nad Orlicí, Einzeichnung der Funde vom Verfasser mit der Software Quantum GIS.

\section{Detektorový průzkum lokality}

Archeologický výzkum při nejednoznačné výpovědi písemných pramenů skýtá hlavní naději pro vyřešení některých otázek spojených s touto lokalitou, výkopy však zatím nebyly na lokalitě provedeny ani v minimální míře. Keramika z povrchových sběrů staršího data se 
nachází v Orlickém muzeu v Chocni (Vích 2009, 14-15), v Národním muzeu v Praze uchovávají hlavici meče, která donedávna unikala pozornosti odborné veřejnosti (Žákovský-Košta-Hošek, $\mathrm{v}$ tisku).

Vzhledem k tomu, že se lokalita stávala cílem nelegálních aktivit ze strany uživatelů detektorů kovů (přičemž několik nálezů bylo předáno do sbírek Regionálního muzea ve Vysokém Mýtě a těžko odhadnutelnou část nálezů v privátním držení se podařilo alespoň zdokumentovat, Vích 2011, 1006, obr. 8:1-4,9), proběhl v režii Regionálního muzea ve Vysokém Mýtě na lokalitě v letech 2007-2011 detektorový průzkum. ${ }^{2}$ Ten se zaměřil na celý hradní kopec, zejména pak na hradní svahy a prŕstupovou šíji spojující hradní kopec s předpolím. Stranou pozornosti v zásadě zůstala pouze plošina hradního jádra se dvěma depresemi interpretovanými jako suterény staveb, protože četné zlomky keramiky zde signalizovaly prrítomnost složitějších intaktních situací, přičemž nebyl k dispozici dostatečně detailní plán lokality ani finanční prostředky na geodetické zaměřování vyzvedávaných kovových artefaktů. To se podařilo až v závěrečné fázi průzkumu z prostř̌edků Regionálního muzea ve Vysokém Mýtě zřizovaného Pardubickým krajem (obr. 2). Jednotlivé předměty jsme proto zaměřovali ruční stanicí GPS značky Garmin Geko 201 a Garmin Oregon 550 se slovní dokumentací jednoduchých stratigrafických poměrů. Pro každou lokalitu zvlášt' včetně Zítkova je vedena tabulka v programu MS Excel, v níž každý artefakt dostal vzestupně přiděleno konkrétní číslo. Pod těmito čísly pak artefakty figurují v soupisové části této práce a v obrázcích (k metodice podrobně Vích 2015). Detektorovou prospekcí se podařilo z hradního kopce získat více než tři stovky artefaktů, přičemž dvě třetiny z nich představují hroty šípů. Těm již spolu s jedním válcovitým olověným projektilem z palné zbraně byla zevrubně věnována pozornost jinde (Vích 2017), zopakujme zde jenom skutečnost, že se hrad stal místem minimálně jedné vojenské události související s jeho dobýváním. Samostatná pozornost byla věnována mimořádnému nálezu torza páru umělecky pojatých bronzových a silně zlacených ostruh nalezených v oblasti výše zmíněné prrístupové šíje (Žákovský-Vích 2019).

Neprovedení prospekce $\mathrm{v}$ areálu hradního jádra mělo později překvapivý důsledek v podobě objevu nádoby s torzem rozstříhaného stříbrného kalicha archeologizovaného někdy koncem 16. až v průběhu 17. století, tedy dávno po opuštění hradu. Nález interpretujeme jako doklad novověké kriminální činnosti v blíže neurčeném kostele spojený s dělením a ukrytím části lupu na morfologicky nápadném místě (podrobně Čechura-Vích 2018).

\section{Katalog kovových nálezů}

Souřadnice GPS jsou ve WGS 84, UTM. Uvedené rozměry byly naměřeny po konzervaci.

\section{Militaria}

tesák

3. jednosečný hrot tesáku, $98 \times 38 \times 8$ mm; E 0585988, N 5539444; absolutní hloubka ca 20 cm, ve sterilní půdě těsně pod tmavou povrchovou vrstvou (obr. 4)

71. záštitný trn tesáku typu $\mathrm{t}_{12 \mathrm{a}} ; 34 \times 27 \times 11 \mathrm{~mm}$; E 0585945 , N 5539471; hl. $20 \mathrm{~cm}, 8 \mathrm{~cm}$ v podloží (obr. 3)

219. na tři kusy rozlomená rukojet' tesáku, patrná hlavice a nýty, 102 (rekonstruováno) $\times 24 \times$ 13 mm; E 0586114, N 5539223; hl. 14 cm, 8 cm v šedém jílovitopísčitém podloží (obr. 3)

2 Na lokalitě jsme nezaznamenávali četnější vkopy detektorového původu představující neklamné př́iznaky nelegálních aktivit. To však dokládá pouze tu skutečnost, že k těmto aktivitám nedocházelo př́imo v době našich aktivit. Rabovací aktivity naopak přímo dokládají dokumentované nálezy v privátních sbírkách (přičemž je jasné, že těžko odhadnutelné množství artefaktů zůstává v jiných, nepř́stupných sbírkách). Nepřimo to dokládá absence větších kovových předmětů na snadno př́stupných plochách svahů hradního jádra. S těmi (např. okutí rýče) jsme se setkávali pouze $\mathrm{v}$ místech $\mathrm{s}$ hustým podrostem. Výjimku tvoři pouze část obruče kola, která se nacházela na dobře př́istupném místě na severním svahu, ale pod pařezem a její vyproštění bylo značně namáhavé. 
272. záštitný trn tesáku typu t ${ }_{11}, 48 \times 27 \times 8$ mm; E 0586020, N 5539496; h1. 15 cm, rozhraní šedé písčité splachové vrstvy a podloží (obr. 3)

kování pochvy

67. plechové nákončí pochvy; $28 \times 28 \times 14 \mathrm{~mm}$; E $0586018, \mathrm{~N} 5539496 ; \mathrm{hl} .12 \mathrm{~cm}$, z toho $6 \mathrm{~cm}$ v hnědošedé jílovitopísčité vrstvě (obr. 3)

\section{Předměty související s jezdcem a koněm}

podkovy

5. zlomek podkovy, $90 \times 25 \times 13 \mathrm{~mm}$; E 0585990 , N 5539463; hl. $10 \mathrm{~cm}$ v humusové vrstvě (obr. 5)

6. zlomek podkovy s hřebem, $114 \times 27 \times 12 \mathrm{~mm}$; E 0586028 , N 5539410; hl. $20 \mathrm{~cm}$ ve sterilním štěrkopísčitém podloží v trase vyježděné terénními motocykly, humusová vrstva zde byla zcela erodována (obr. 5)

8. polovina podkovy, $109 \times 30 \times 15 \mathrm{~mm}$; E 0586048, N 5539371; hl. $25 \mathrm{~cm}, 5 \mathrm{~cm}$ v šedorezavém štěrkopísku (obr. 5)

15. polovina podkovy, $112 \times 31 \times 15 \mathrm{~mm}$; E 0586064 , N 5539371; hl. $10 \mathrm{~cm}$ na rozhraní humusové vrstvy a štěrkopísčitého podloží (obr. 5)

17. zlomek ramena podkovy s ozubem a dochovaným hřebem, $88 \times 23 \times 23 \mathrm{~mm}$; E 0586035 , N 5539384; hl. 25 cm, 18 cm v čistém štěrkopísku (obr. 5)

25. zhruba polovina podkovy bez hmatce, $107 \times 27 \times 16 \mathrm{~mm}$; E 0586066, N 5539350; hl. $15 \mathrm{~cm}$, rozhraní humusové vrstvy a podloží (obr. 8)

31. zlomek ramena podkovy s ozubem, $70 \times 27 \times 12 \mathrm{~mm}$; E 0586010, N 5539524; hl. $20 \mathrm{~cm}, 13 \mathrm{~cm}$ ve sterilním podloží (obr. 7)

53. větší polovina podkovy s ozubem bez hmatce, $119 \times 64 \times 29$ mm; E 0585995, N 5539502; hl. $26 \mathrm{~cm}, 10 \mathrm{~cm}$ v podložním štěrkopísku (obr. 6)

54. necelá polovina podkovy s ozubem, $114 \times 28 \times 22 \mathrm{~mm}$; E 0586009 , N 5539498; hl. $18 \mathrm{~cm}$, $12 \mathrm{~cm}$ v jílovitém podloží u paty pařezu (obr. 6)

55. zlomek ramena podkovy s ozubem a žlábkem, $87 \times 30 \times 16 \mathrm{~mm}$; E 0586012, N 5539502; hl. $12 \mathrm{~cm}, 2 \mathrm{~cm}$ v podloží, humusová vrstva erodována (obr. 9)

56. zlomek ramena podkovy s ozubem, $89 \times 29 \times 24$ mm; E 0586009, N 5539498; hl. $12 \mathrm{~cm}, 4 \mathrm{~cm}$ v šedé jílovitopísčité vrstvě (obr. 9)

57. zlomek ramena podkovy s ozubem, $71 \times 23 \times 17 \mathrm{~mm}$; E 0586012, N 5539494; hl. $18 \mathrm{~cm}, 10 \mathrm{~cm}$ ve sterilním podloží (obr. 9)

58. větší část podkovy s ozubem bez hmatce, $102 \times 75 \times 19$ mm; E 0586029, N 5539499; hl. 20 cm, $8 \mathrm{~cm}$ v podloží (obr. 6)

59. větší polovina podkovy bez hmatce s ozubem, $111 \times 34 \times 19 \mathrm{~mm}$; E 0586031, N 5539500; hl. $4 \mathrm{~cm}$ v šedé jílovité či humusové vrstvě (obr. 6)

82. polovina masivní podkovy s ozubem bez hmatce, $142 \times 35 \times 24 \mathrm{~mm}$; E 0586064, N 5539473; pohozeno volně pod listím jako důsledek nelegální činnosti (obr. 8) 

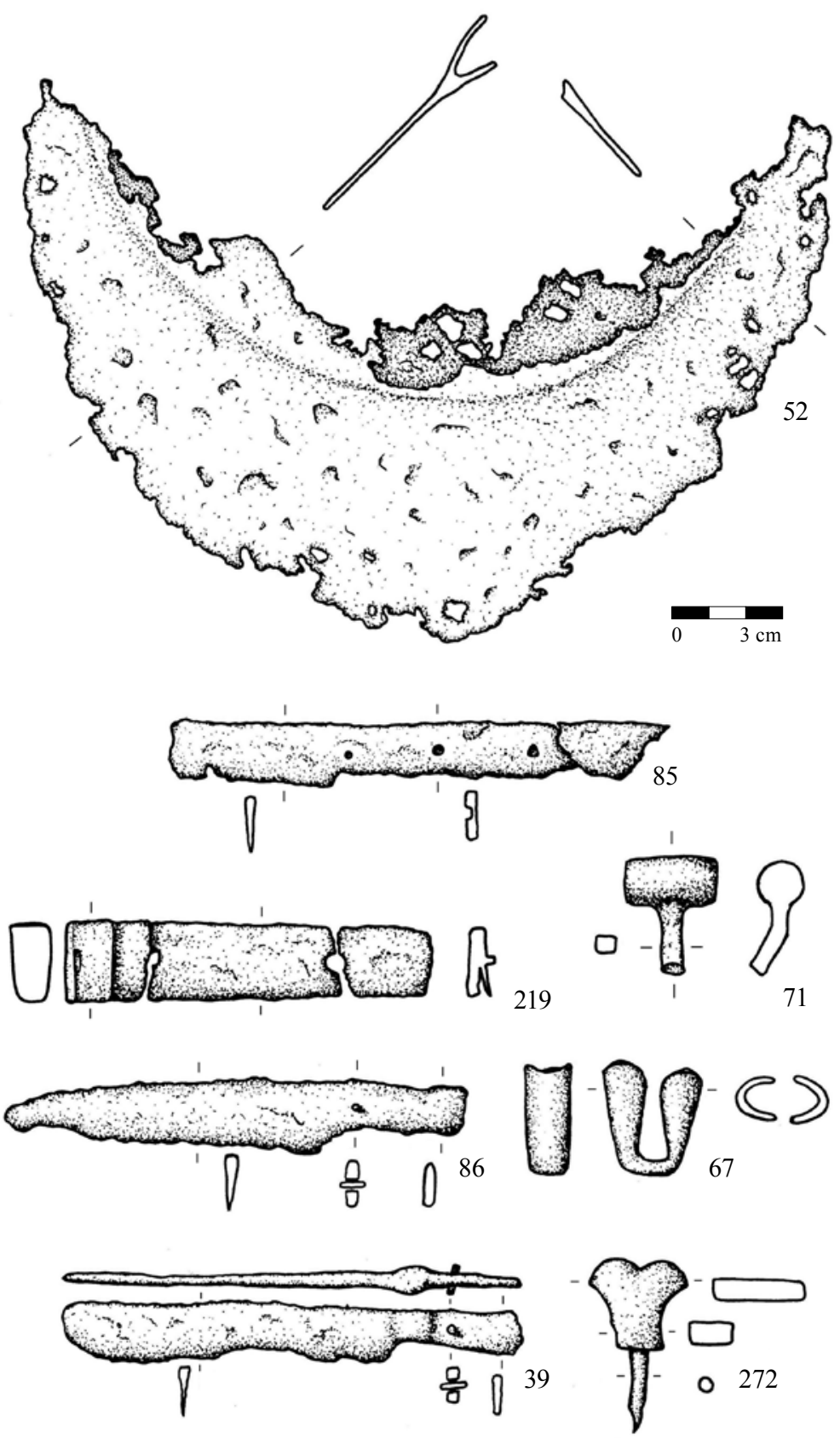

Obr. 3. Železné artefakty z lokality. 52 - okutí rýče, 71, 219, 272 - tesáky a jejich části, 67 - nákončí pochvy, 39, 85, 86 - nože a jejich části. Kresba Tomáš Záruba.

Abb. 3. Eisenartefakte von der Fundstätte. 52 - Spatenblattansatz, 71, 219, 272 - Jagdmesser und Jagdmesserteile, 67 - Ortband einer Scheide, 39, 85, 86 - Messer und Messerteile. Zeichnung Tomáš Záruba. 

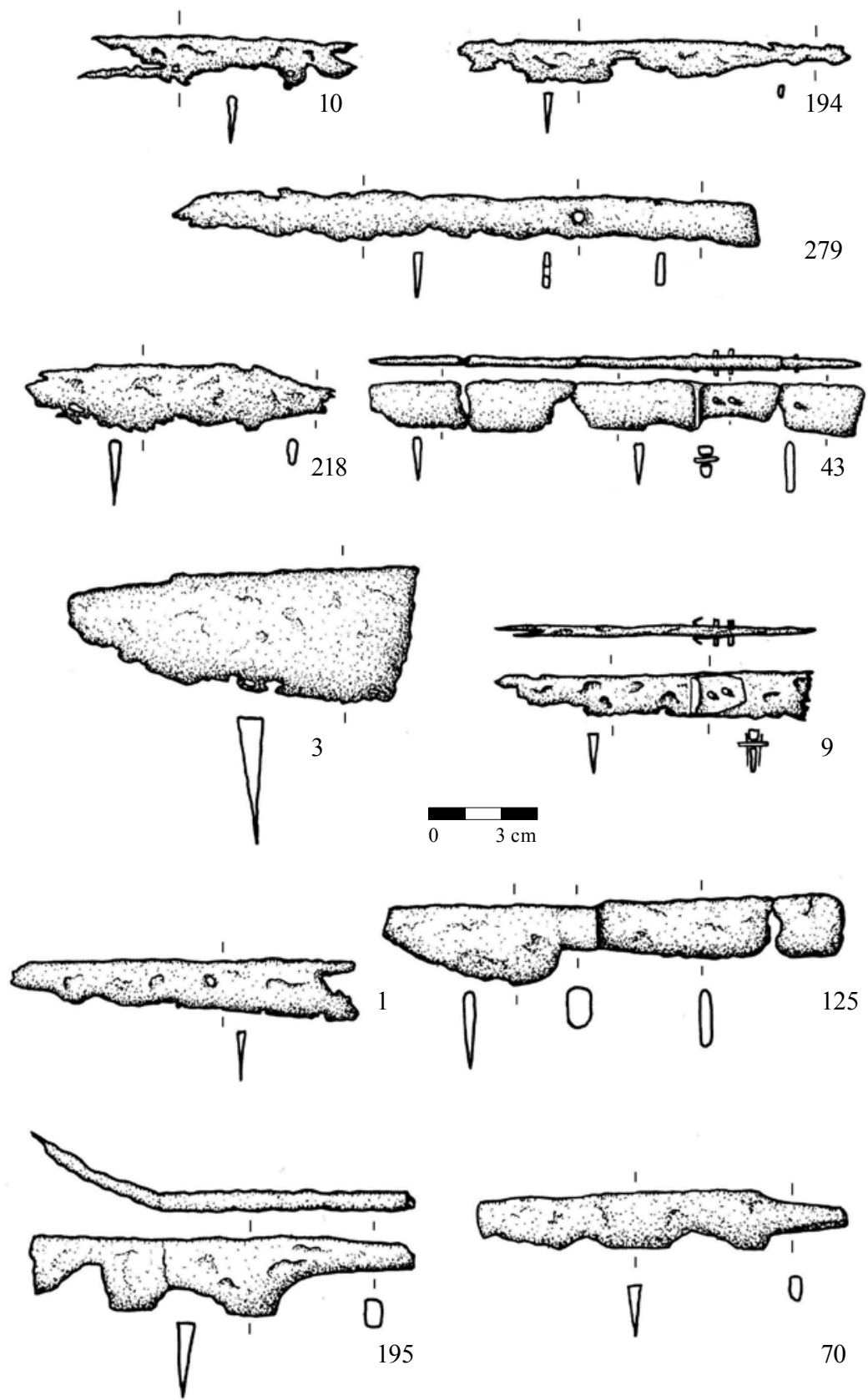

70

Obr. 4. Železné artefakty z lokality. 3 - zlomek čepele tesáku, 1, 9, 10, 43, 70, 125, 194, 195, 218, 279 - nože a jejich části. Kresba Tomáš Záruba.

Abb. 4. Eisenartefakte von der Fundstätte. 3 - Klingenfragment eines Jagdmessers, 1, 9, 10, 43, 70, 125, 194, 195, 218, 279 Messer und Messerteile. Zeichnung Tomáš Záruba. 

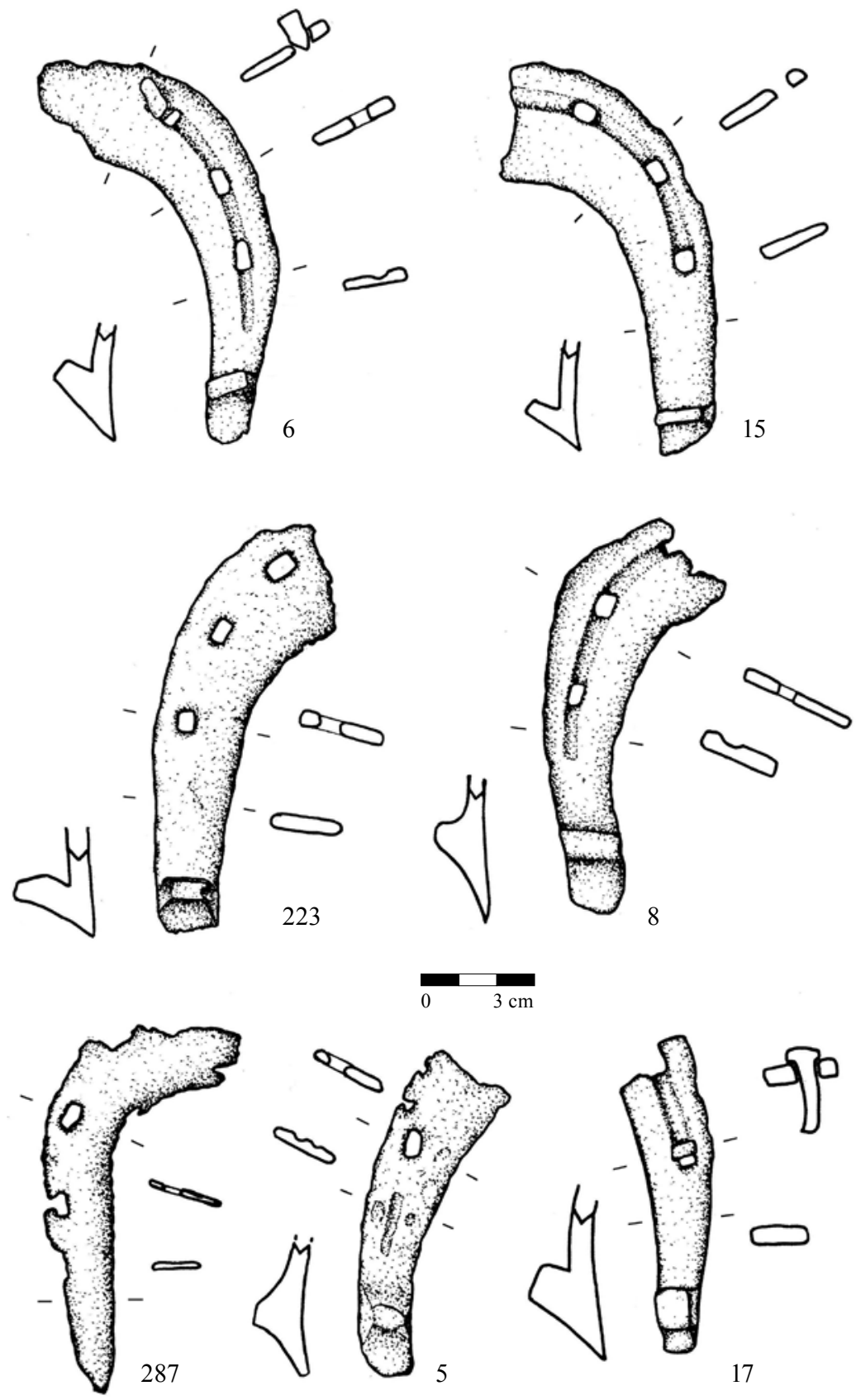

Obr. 5. Železné artefakty z lokality. Podkovy. Kresba Tomáš Záruba.

Abb. 5. Eisenartefakte von der Fundstätte. Hufeisen. Zeichnung Tomáš Záruba. 

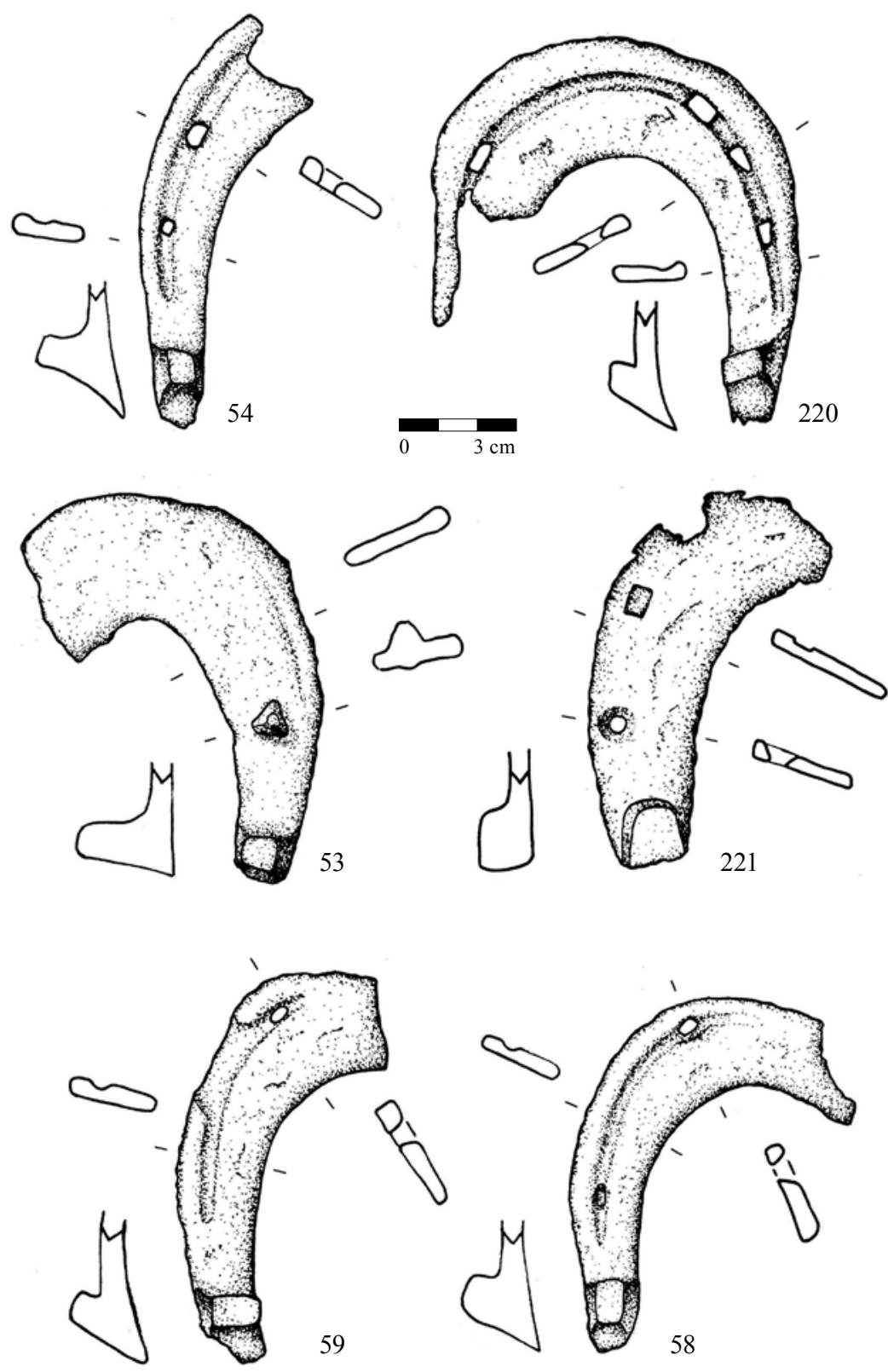

Obr. 6. Železné artefakty z lokality. Podkovy. Kresba Tomáš Záruba.

Abb. 6. Eisenartefakte von der Fundstätte. Hufeisen. Zeichnung Tomáš Záruba. 

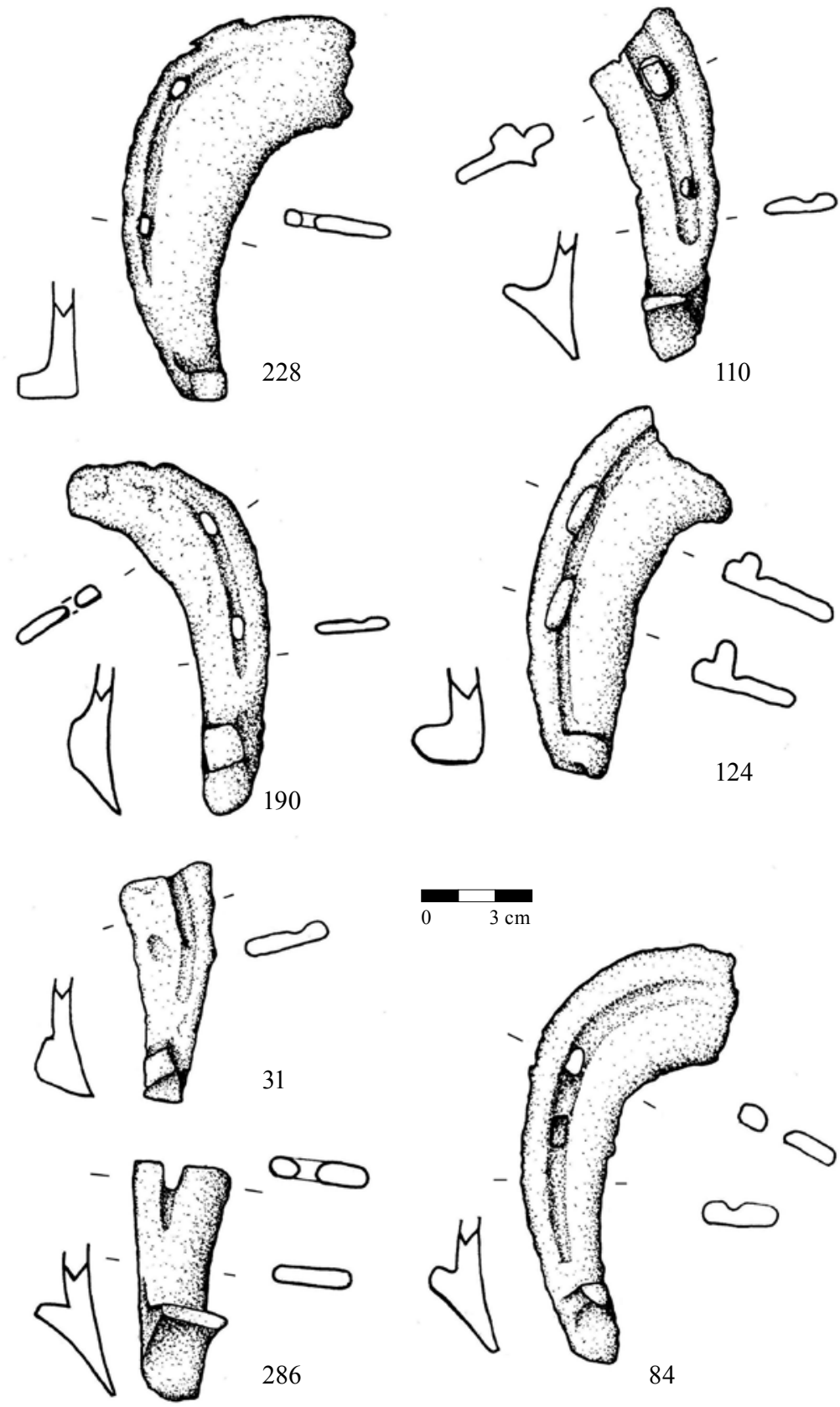

Obr. 7. Železné artefakty z lokality. Podkovy. Kresba Tomáš Záruba.

Abb. 7. Eisenartefakte von der Fundstätte. Hufeisen. Zeichnung Tomáš Záruba. 

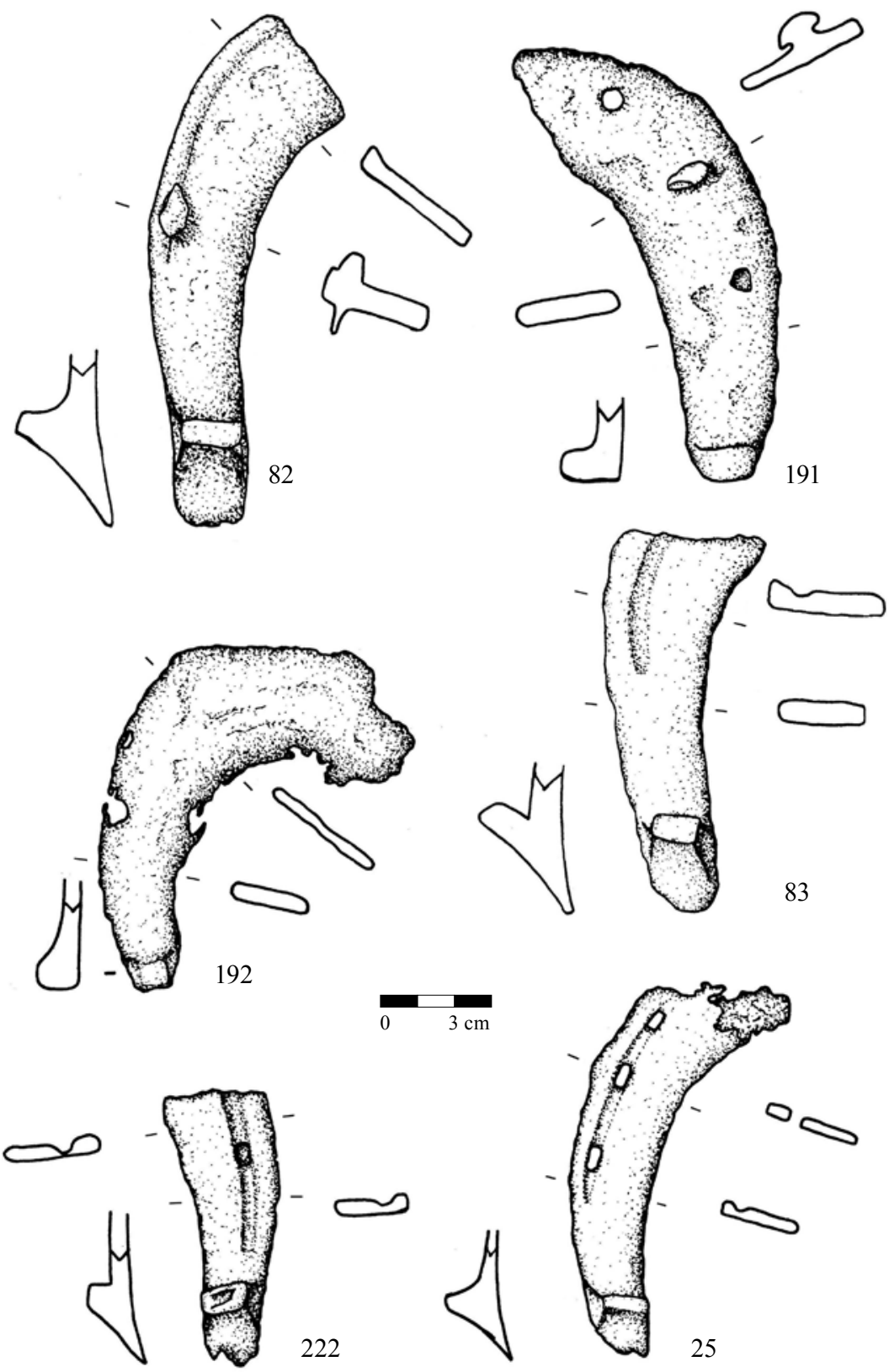

Obr. 8. Železné artefakty z lokality. Podkovy. Kresba Tomáš Záruba.

Abb. 8. Eisenartefakte von der Fundstätte. Hufeisen. Zeichnung Tomáš Záruba. 

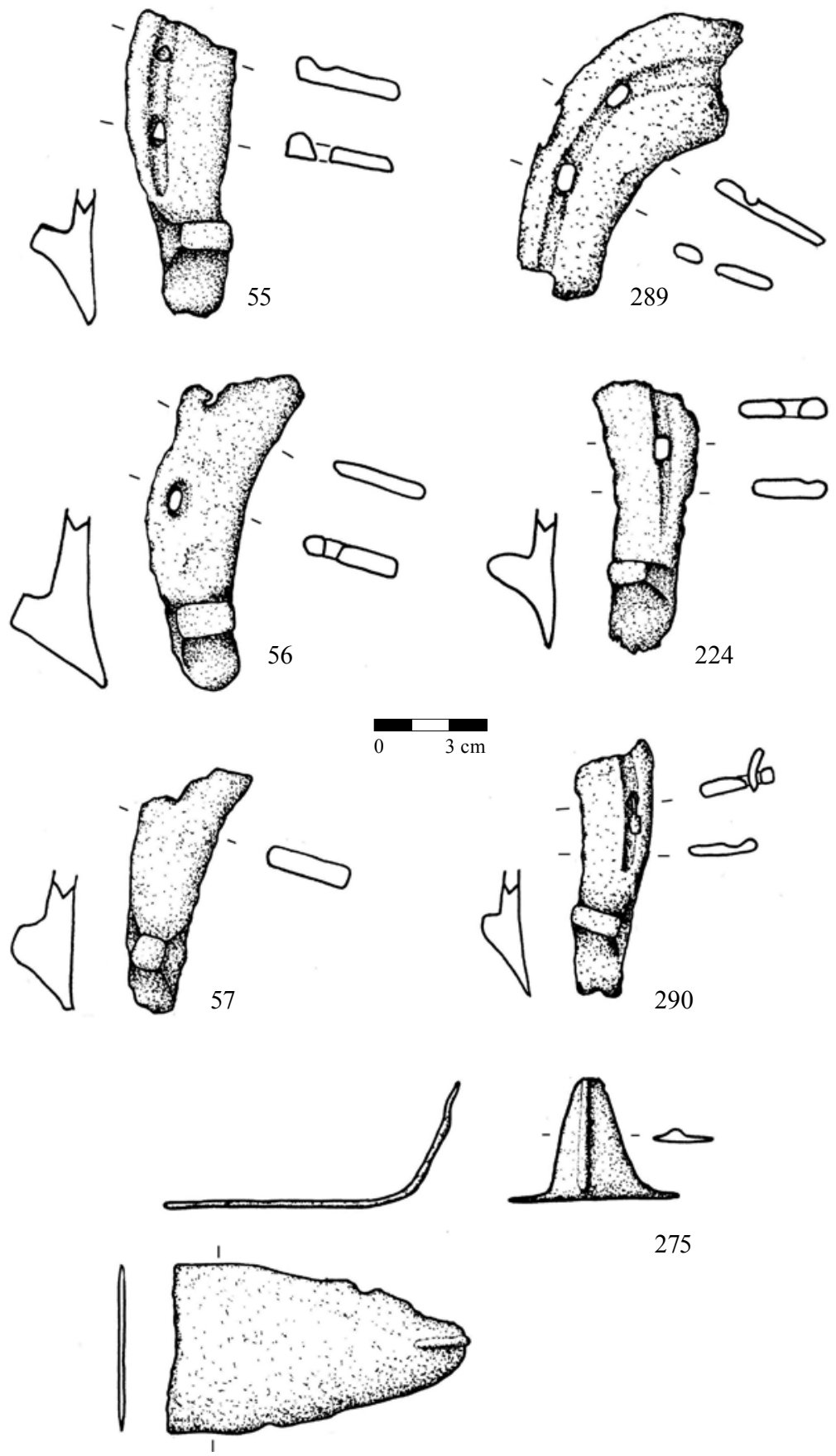

Obr. 9. Železné artefakty z lokality. 55, 56, 57, 224, 289, 290 - podkovy, 275 - zlomek třmene. Kresba Tomáš Záruba. Abb. 9. Eisenartefakte von der Fundstätte. 55, 56, 57, 224, 289, 290 - Hufeisen, 275 - Steigbügelfragment. Zeichnung Tomáš Záruba. 
83. část ramena podkovy s ozubem, $104 \times 41 \times 25$ mm; E 0586092, N 5539460; pod listím, patrně pohozeno při nelegální činnosti (obr. 8)

84. větší polovina podkovy s ozubem bez hmatce, $119 \times 35 \times 15 \mathrm{~mm}$; E 0586062 , N 5539484; pod listím, pohozeno při nelegální činnosti (obr. 7)

110. menší část podkovy s ozubem a hřebem, $98 \times 30 \times 19$ mm; E 0585979, N 5539333; hl. 24 cm, $10 \mathrm{~cm}$ v podloží (obr. 7)

124. necelá polovina podkovy s ozubem a hřeby, $106 \times 41 \times 23 \mathrm{~mm}$; E 0586106 , N 5539392; hl. do $10 \mathrm{~cm}$ v humusové vrstvě (obr. 7)

190. větší polovina podkovy bez hmatce, $104 \times 27 \times 11 \mathrm{~mm}$; E 0585990, N 5539334; hl. $10 \mathrm{~cm}$, $6 \mathrm{~cm}$ v podloží (obr. 7)

191. větší polovina podkovy bez hmatce, $132 \times 37$ × $16 \mathrm{~mm}$; E 0585931, N 5539541; hl. $10 \mathrm{~cm}$ na rozhraní podloží a humusové vrstvy (obr. 8)

192. větší část podkovy, $110 \times 37 \times 12 \mathrm{~mm}$; E 0585995, N 5539268; hl. $28 \mathrm{~cm}, 10 \mathrm{~cm}$ v podloží (obr. 8)

220. větší část podkovy s ozubem bez hmatce, $100 \times 92 \times 14 \mathrm{~mm}$; E 0586106 , N 5539408; hl. $14 \mathrm{~cm}$ v tmavé jílovitopísčité, patrně humusové vrstvě (obr. 6)

221. polovina podkovy s ozubem, $112 \times 35 \times 15 \mathrm{~mm}$; E $0586088, \mathrm{~N} 5539410 ; \mathrm{hl} .34 \mathrm{~cm}$ ve splachu (obr. 6)

222. zlomek ramena podkovy s ozubem, $76 \times 29 \times 14 \mathrm{~mm}$; E $0586034, \mathrm{~N} 5539340$; hl. $10 \mathrm{~cm}$ na rozhraní (obr. 8)

223. zhruba polovina podkovy s ozubem, $116 \times 32 \times 20 \mathrm{~mm}$; E 0586140 , N 5539303; hl. $5 \mathrm{~cm}$ na rozhraní (obr. 5)

224. zlomek ramena podkovy s ozubem, $74 \times 25 \times 21 \mathrm{~mm}$; E 0586076 , N 5539313; hl. $4 \mathrm{~cm} \mathrm{z} \mathrm{roz-}$ hraní (obr. 9)

286. zlomek ramena podkovy bez ozubu, $67 \times 25 \times 19 \mathrm{~mm}$; E 0586003, N 5539475; hl. $20 \mathrm{~cm}$, $14 \mathrm{~cm}$ v rezavošedém štěrkopísku (obr. 7)

287. polovina podkovy s ozubem tvořeným lehce prohnutým koncem ramena, $105 \times 24 \times 4 \mathrm{~mm}$; E 0586036, N 5539504; hl. 20 cm, 16 cm v šedé písčité vrstvě (obr. 5)

288. polovina podkovy s ozubem, $112 \times 38 \times 17 \mathrm{~mm}$; E 0585989 , N 5539563; hl. $30 \mathrm{~cm}, 22 \mathrm{~cm}$ v jílovité vrstvě (obr. 7)

289. část ramena podkovy, konec s ozubem odlomen, $89 \times 37 \times 5 \mathrm{~mm}$; E 0586019, N 5539388; volně pod listím (obr. 9)

290. zlomek ramena podkovy s ozubem s hřeby, $72 \times 21 \times 15 \mathrm{~mm}$; E 0586039, N 5539476; hl. $20 \mathrm{~cm}$ na rozhraní šedé písčité splachové vrstvy a podloží (obr. 9)

ostruhy

47. celá ostruha včetně upínacího mechanismu a velkého kolečka ve vidlici, $148 \times 71 \times 40 \mathrm{~mm}$; E 0585977 , N 5539445; hl. 20 cm, 8 cm ve štěrkopísčitém podloží, s větším opukovým kamenem (obr. 11)

76. kolečko ostruhy o osmi paprscích, $40 \times 38 \times 6$ mm; E 0585944, N 5539456; hl. $10 \mathrm{~cm}$ na rozhraní humusové vrstvy a podloží (obr. 11) 


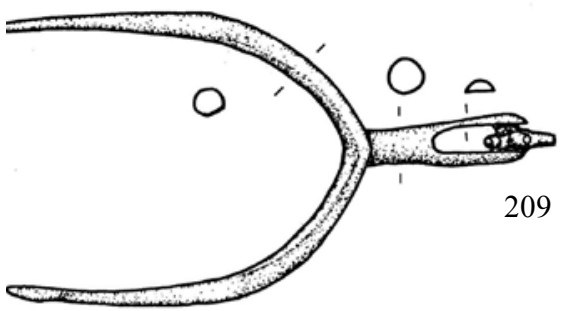

78. rameno ostruhy s obdélníkovitým úchytem se dvěma otvory, $98 \times 17 \times 7 \mathrm{~mm}$; E 0586079 , N 5539471; hl. $20 \mathrm{~cm}$ na rozhraní humusové vrstvy a jílovitého podloží (obr. 10)

122. ostruha s parabolickými rameny s kruhovým př́čným průřezem a $\mathrm{s}$ koncovými úchyty s dvojicí otvorů, $113 \times 110 \times 42 \mathrm{~mm}$; E 0586049, N 5539432; získáno z vývratu dubu po kalamitě z 25. 6. 2008 na svahu akropole spolu s množstvím keramiky při rozebírání vývratu v rámci projektové výuky (7. tř.

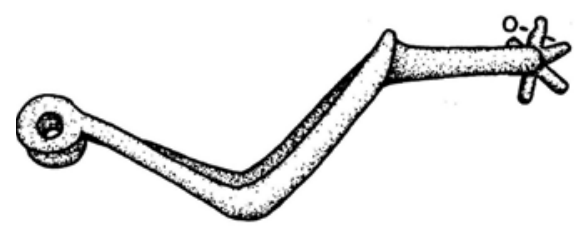

ZŠ Sv. Čecha, Choceň, obr. 11)

126. velké kolečko ostruhy s osmi paprsky, $55 \times 49 \times 7 \mathrm{~mm}$; E 0586032 , N 5539363; hl. $22 \mathrm{~cm}, 15 \mathrm{~cm}$ v podloží (obr. 10)

196. deformovaná ostruha s prohnutými rameny ukončenými osmičkovitými úchyty a vidlicí bez kolečka, $135 \times 55 \times 48 \mathrm{~mm}$;
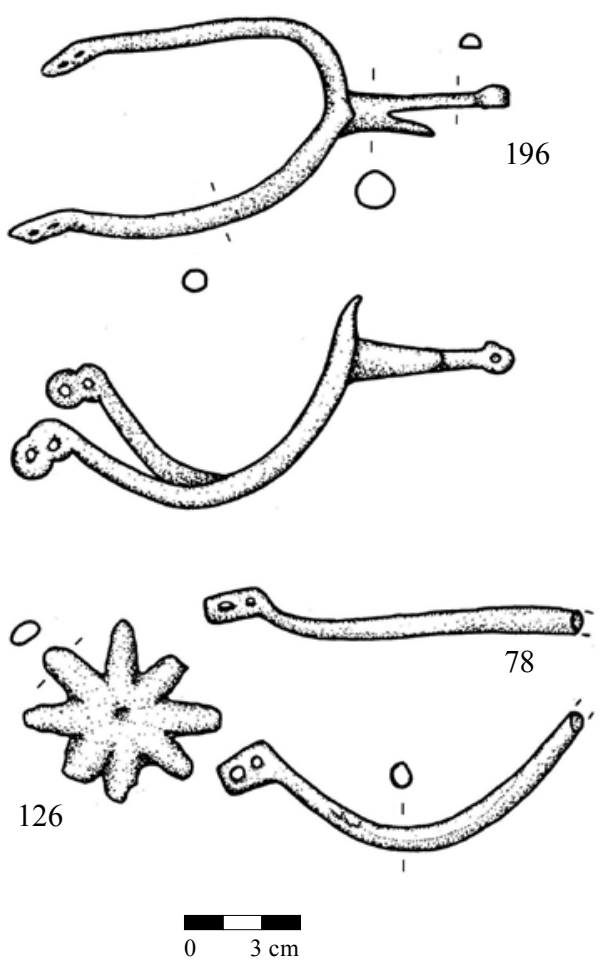
E 0585994, N 5539402; hl. 20 cm v šedé písčité vrstvě (obr. 10)

197. torzo ostruhy s krátkou vidlicí s kolečkem, konce ramen odlomeny, $114 \times 83 \times$ $37 \mathrm{~mm}$; E 0586001, N 5539257; hl. $15 \mathrm{~cm}, 6 \mathrm{~cm}$ v podloží (obr. 11)

209. ostruha se zalomenými rameny a v podstatě jednoduchými kruhovými úchyty, dochováno kolečko o šesti paprscích, $142 \times 80 \times$ $40 \mathrm{~mm}$; E 0586122, N 5539352; hl. $15 \mathrm{~cm}$, $10 \mathrm{~cm}$ v hnědošedém štěrkopísku (obr. 10)

283. torzo ostruhy s částí ramena a pyramidovitě ukončeným bodcem, $70 \times 33 \times 11 \mathrm{~mm}$; E 0586048, N 5539263; hl. $10 \mathrm{~cm}$ na rozhraní humusové vrstvy a písčité hnědošedé vrstvy (obr. 11)

třmen

275. zlomek stupadla třmene zhotoveného z plechu, $83 \times 47 \times 31 \mathrm{~mm}$; E 0586009 , N 5539486; hl. 22 cm, 16 cm v šedém štěrkopísčitém splachu s ojedinělou keramikou (obr. 9)

udidlo

Obr. 10. Železné artefakty z lokality. Ostruhy. Kresba Tomáš Záruba.

Abb. 10. Eisenartefakte von der Fundstätte. Sporen. Zeichnung Tomáš Záruba.

274. dvoudílné stíhlové udidlo, s kloubem, v zakorodovaném stavu, $135 \times 35 \times 14 \mathrm{~mm}$; E 0586023, N 5539254; hl. $12 \mathrm{~cm}$ na rozhraní humusové vrstvy a prachovitého podloží (obr.

12) 

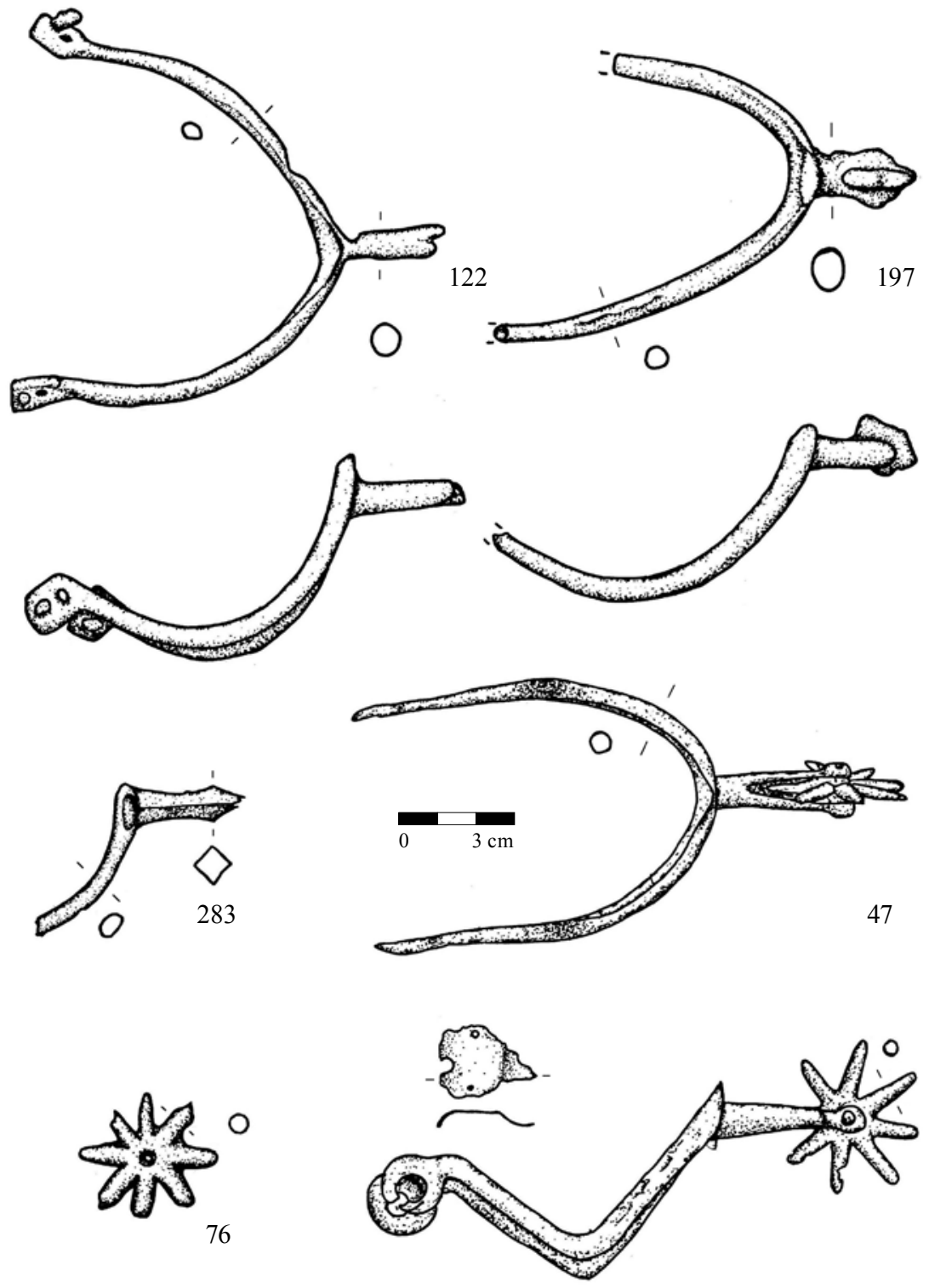

Obr. 11. Železné artefakty z lokality. Ostruhy. Kresba Tomáš Záruba.

Abb. 11. Eisenartefakte von der Fundstätte. Sporen. Zeichnung Tomáš Záruba. 
276. udítko, $90 \times 20 \times 9 \mathrm{~mm}$; nezaměřeno; hl. $33 \mathrm{~cm}$, z toho $3 \mathrm{~cm}$ humusová vrstva, $14 \mathrm{~cm}$ šedá písčitá (splach) a $6 \mathrm{~cm}$ v rezavém štěrkopísku (obr. 12)

\section{hřeblo}

193. celé hřeblo, $150 \times 141 \times 49$ mm; E 0585995 , N 5539268; hl. $13 \mathrm{~cm}$ na povrchu podloží (obr. 12)

\section{zákolnik}

114. zákolník, $155 \times 40 \times 10$ mm; E 0585976 , N 5539458; hl. 14 cm, 8 cm ve štěrkopísčitém podloží pod hranou cesty (obr. 12)

obruč z kola

273. zlomek obruče kola, $225 \times 40 \times 4$ mm; E 0586025, N 5539514; pod pařezem v šedé jílovité vrstvě, bez možnosti objektivně změřit hloubku (obr. 14)

\section{Předměty osobní potřeby}

nože

1. torzo nože s řapem, $98 \times 17 \times 3$ mm; E 0585993 , N 5539444; hrana akropole nad př́ikopem, místo rozježděné terénními motocykly, hl. $7 \mathrm{~cm}$ (obr. 4)

9. zlomek nože s částí čepele a řapu s nýty, čepel od rukojeti odděluje plíšek ze slitiny mědi, $90 \times$ $13 \times 8 \mathrm{~mm}$; E 0586052 , N 5539389; hl. 10-15 cm na rozhraní humusové vrstvy a štěrkopísčitého podloží (obr. 4)

10. zlomek nože s částí čepele a řapu, $80 \times 14 \times 3$ mm; E 0586067, N 5539393; hl. 15 cm na rozhraní humusové vrstvy a štěrkopísčitého podloží (obr. 4)

39. zlomek nože s částí čepele a řapu, $128 \times 16 \times 9 \mathrm{~mm}$; E 0585975, N 5539338; hl. $12 \mathrm{~cm}$ při bázi humusové vrstvy, poprrípadě na rozhraní humusové vrstvy a štěrkopísčitého podloží (obr. 3)

43. na čtyři části rozlámaný nůž s částí řapu, ca $137 \times 15 \times 7 \mathrm{~mm}$; E 0585965, N 5539381; hl. $16 \mathrm{~cm}, 6 \mathrm{~cm}$ ve sterilním podloží - jíl přecházející ve štěrkopísek (obr. 4)

70. nůž s odlomeným hrotem a částečně odlomeným trnem pro naražení rukojeti, $98 \times 17 \times$ $5 \mathrm{~mm}$; E 0585967, N 5539515; hl. $12 \mathrm{~cm}, 10 \mathrm{~cm}$ v podloží (obr. 4)

85. nůž s částečně odlomeným řapem a větší částí čepele, $138 \times 17 \times 6 \mathrm{~mm}$; E 0586078 , N 5539407; hl. 25 cm, 5 cm ve sterilním štěrkopísku (obr. 3)

86. nůž $\mathrm{s}$ částečně odlomeným řapem a obloukovitě prohnutým hřbetem, $129 \times 20 \times 8 \mathrm{~mm}$; E 0586025, N 5539358; hl. 7 cm na rozhraní humusové vrstvy a podloží (obr. 3)

125. nůž s řapem, $130 \times 23 \times 8$ mm; E 0585959, N 5539495; hl. $1 \mathrm{~cm}$ v humusové vrstvě (obr. 4)

194. zlomek nože s částí čepele a řapu, $112 \times 12 \times 6$ mm; E 0585950, N 5539576; hl. 11 cm, rozhraní podloží a humusové vrstvy (obr. 4)

195. torzo nože s trnem, $116 \times 23 \times 7 \mathrm{~mm}$; E 0585972, N 5539568; hl. $21 \mathrm{~cm}, 14 \mathrm{~cm}$ v podloží (obr. 4)

218. torzo nože s trnem, $86 \times 19 \times 4 \mathrm{~mm}$; E 0586059 , N 5539270; hl. $10 \mathrm{~cm}, 6 \mathrm{~cm}$ v písčitém podloží (obr. 4) 

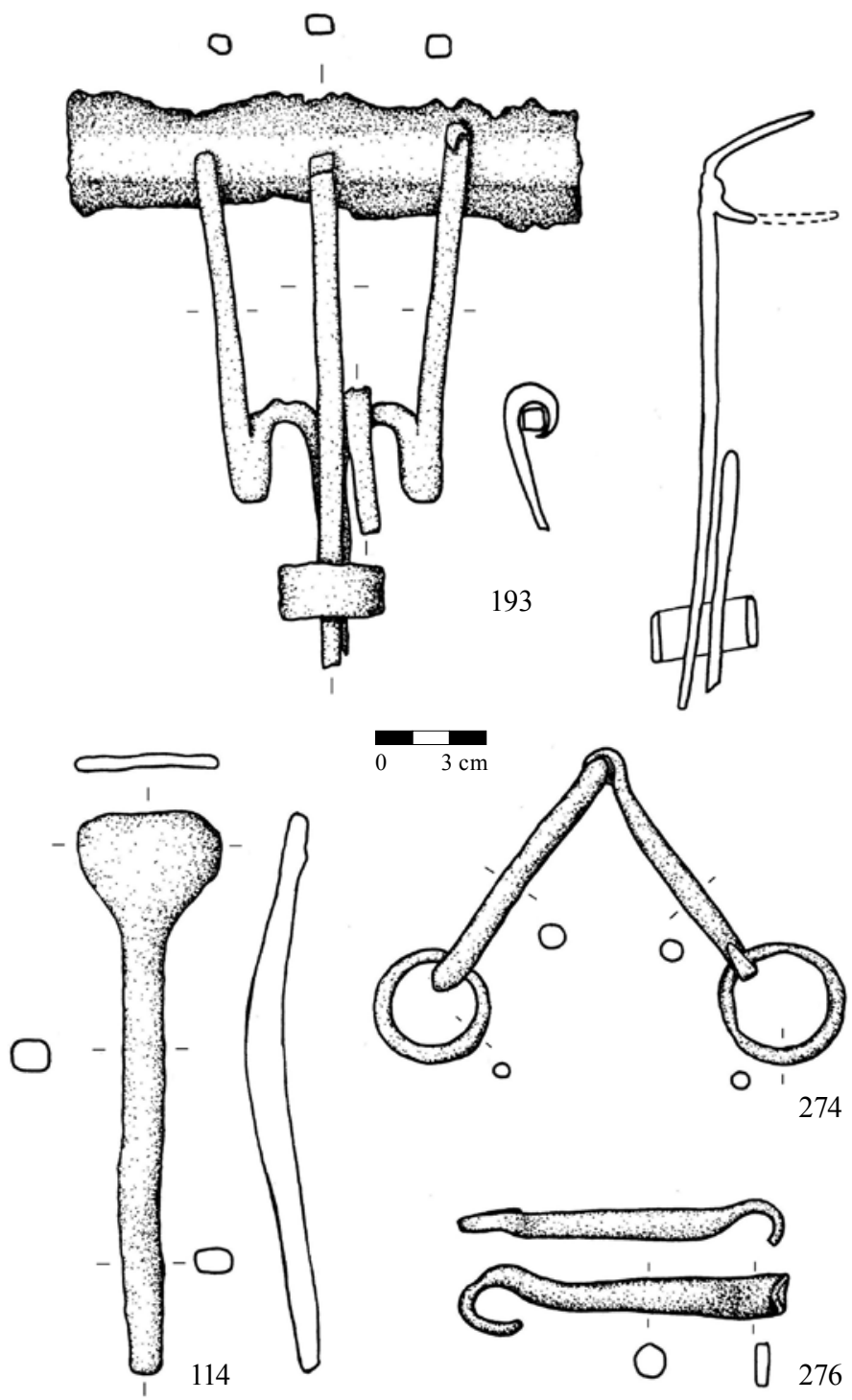

Obr. 12. Železné artefakty z lokality. 193 - hřeblo, 114 - zákolník, 274, 276 - udidla a jejich části. Kresba Tomáš Záruba. Abb. 12. Eisenartefakte von der Fundstätte. 193 - Striegel, 114 - Radnagel, 274, 276 - Zaumzeug und Zaumzeugteile. Zeichnung Tomáš Záruba.

271. torzo nože, $35 \times 12 \times 5 \mathrm{~mm}$; E 0586001 , N 5539331; hl. $20 \mathrm{~cm}, 13 \mathrm{~cm}$ ve štěrkopísku (nekresleno)

279. nůž s řapem, $195 \times 14 \times 3 \mathrm{~mm}$; E 0586002 , N 5539256; hl. $13 \mathrm{~cm}, 6 \mathrm{~cm}$ v písčitém podloží (obr. 4) 

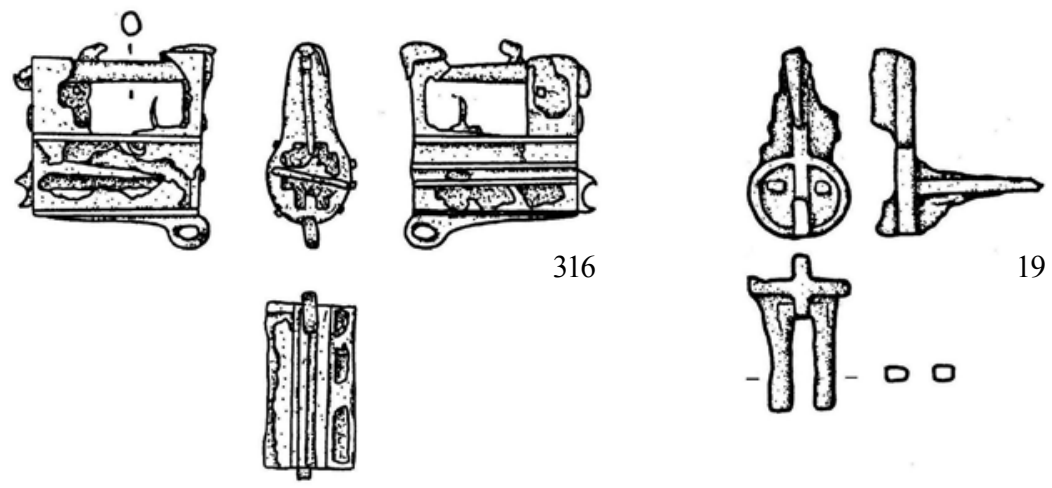

316

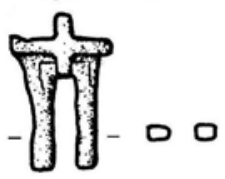

19
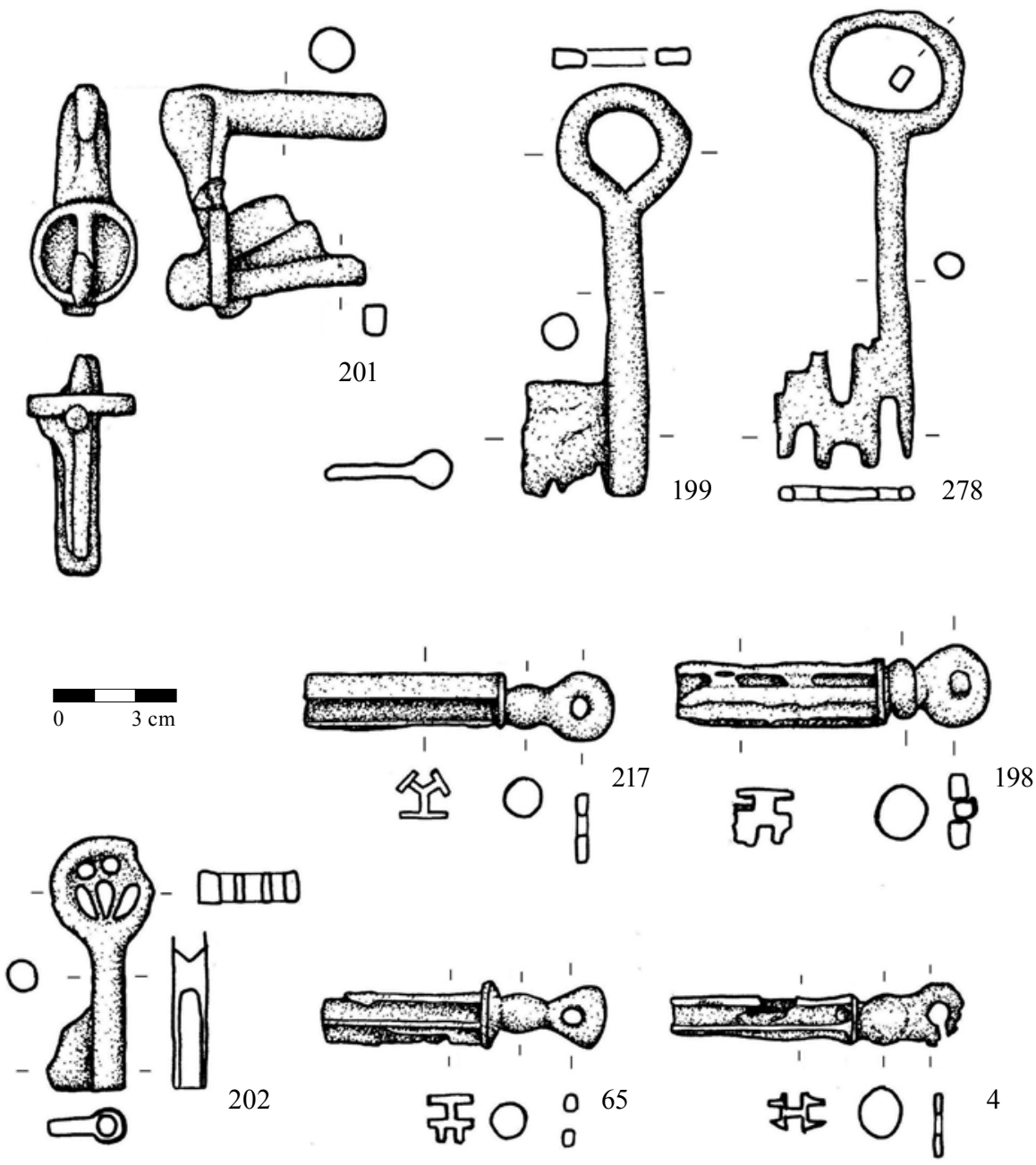

Obr. 13. Železné artefakty z lokality. 19, 201, 316 - zámky, 199, 202, 278 - otočné klíče, 4, 65, 198, 217 - lamelové klíče. Kresba Tomáš Záruba.

Abb. 13. Eisenartefakte von der Fundstätte. 19, 201, 316 - Schlösser, 199, 202, 278 - Drehschlüssel, 4, 65, 198, 217 - Lamellenschlüssel. Zeichnung Tomáš Záruba. 

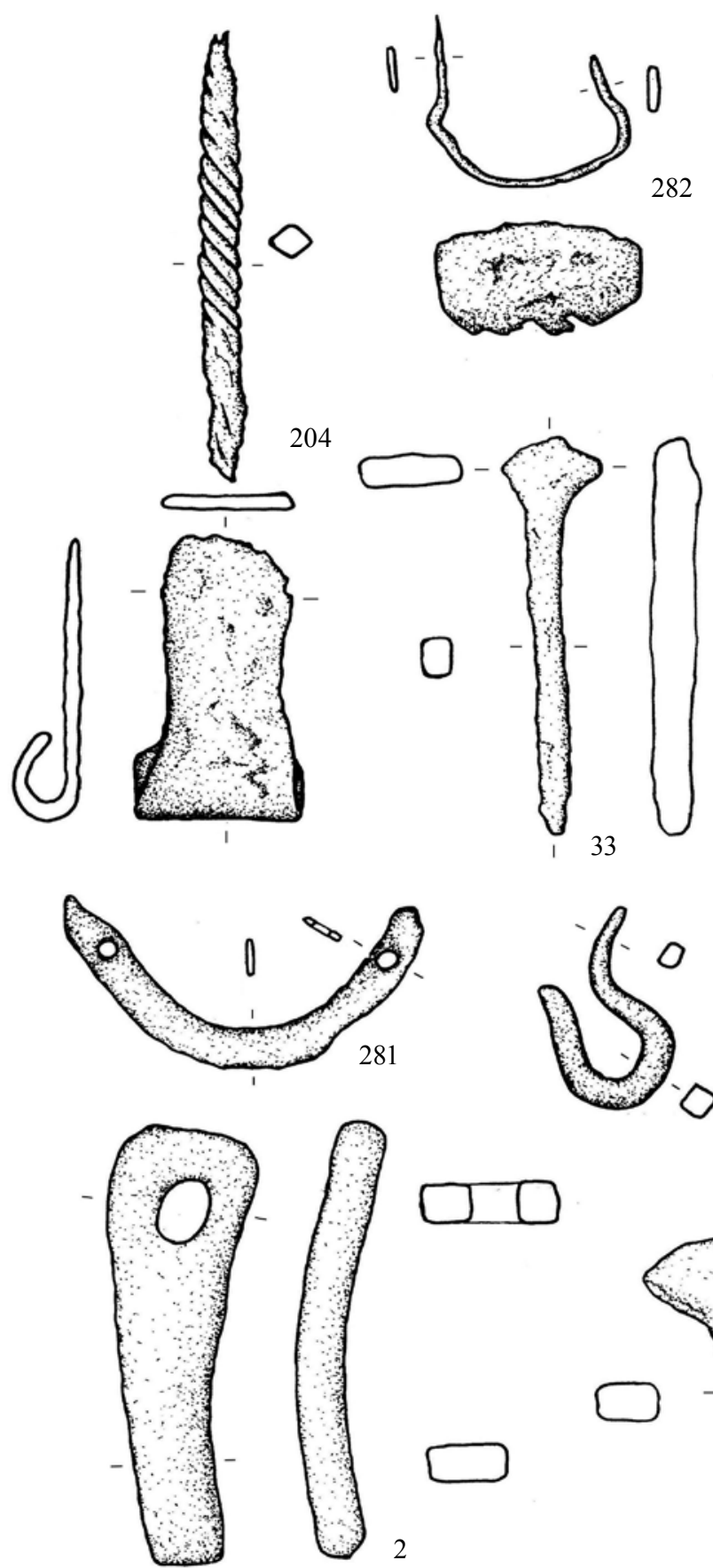

33
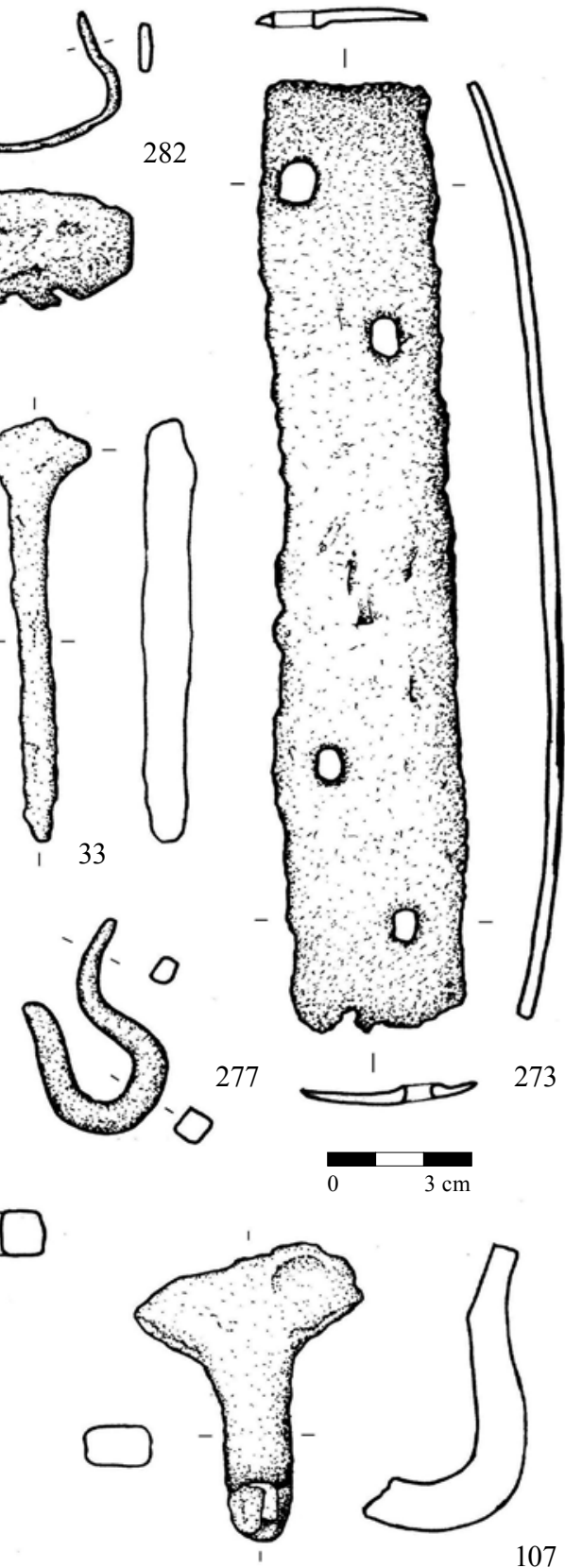

107

Obr. 14. Železné artefakty z lokality. 373 - zlomek obruče kola, 281 - podkůvka z boty, 2, 33, 107, 204, 277, 282 - neurčené předměty. Kresba Tomáš Záruba.

Abb. 14. Eisenartefakte von der Fundstätte. 373 - Fragment eines Radreifs, 281 - Schuhsohlenbeschlag, 2, 33, 107, 204, 277, 282 - unbestimmte Gegenstände. Zeichnung Tomáš Záruba. 
přezky

46. rámeček trapezovité přezky, $64 \times 42 \times 7 \mathrm{~mm}$; E 0585966, N 5539423; volně na povrchu na listí, patrně pozůstatek nelegálních aktivit (obr. 16)

200. rozlomený obdélný rámeček přezky s trnem, $71 \times 56 \times 14 \mathrm{~mm}$; E 0585953, N 5539551; SV svah, hl. $20 \mathrm{~cm}, 10 \mathrm{~cm}$ v podloží (obr. 16)

\section{Stavební kování a předměty spojené s uzamykáním}

\section{kliče}

4. lamelový zásuvný klíč s očkem, $70 \times 15 \times 14 \mathrm{~mm}$; E 0586008 , N 5539420; hl. ca $20 \mathrm{~cm}$ ve sterilní půdě těsně pod tmavou povrchovou vrstvou (obr. 13)

65. lamelový zásuvný klíč s očkem, $68 \times 16 \times 13$ mm; E 0585997, N 5539505; hl. 24 cm, 6 cm $\mathrm{v}$ podloží pod kořeny pařezu mohutného buku (obr. 13)

198. zásuvný lamelový klíč, 75 × $19 \times 14$ mm; E 0585982, N 5539461; hl. 20 cm v hnědošedém štěrkopísku (obr. 13)

199. otočný klíč s plným dříkem, $100 \times 30 \times 10$ mm; E 0585953, N 5539388; hl. 22 cm, 12 cm v podloží (obr. 13)

202. otočný klíček s prolamovaným okem, $62 \times 25 \times 9$ mm; E 0585939, N 5539401; hl. 13 cm na rozhraní humusové vrstvy a podloží či splachu (obr. 13)

217. zásuvný lamelový klíč, $73 \times 17 \times 14$ mm; E 0586117, N 5539312; hl. $10 \mathrm{~cm}$ na rozhraní (obr. 13)

278. otočný klíč s kruhovým okem a plným dříkem, $110 \times 34 \times 18$ mm; E 0586033, N 5539262; h1. $10 \mathrm{~cm}$ na rozhraní humusové vrstvy a písčitého podloží (obr. 13)

zámky

19. vyjímatelná část třmenového závěsného zámku, $41 \times 22 \times 34 \mathrm{~mm}$; E 0586025 , N 5539460; hl. $16 \mathrm{~cm}, \mathrm{z}$ toho $10 \mathrm{~cm}$ v čistém štěrkopísku (obr. 13)

201. vyjímatelná část třmenového závěsného zámku, $59 \times 57 \times 26$ mm; E 0585974, N 5539421; hl. $20 \mathrm{~cm}$, z toho $6 \mathrm{~cm}$ v šedé písčité vrstvě (obr. 13)

316. torzo svorníkového pružinového zámku pájeného mědí, $44 \times 40 \times 21 \mathrm{~mm}$; E 0586040 , N 5539260; hl. $18 \mathrm{~cm}, \mathrm{z}$ toho $9 \mathrm{~cm}$ v písčitém podloží (obr. 13)

ostatni stavebni kováni (?)

2. předmět přibližně kapkovitého tvaru $\mathrm{z}$ hranolu železa na užším konci př́ičně rovně ukončený, uprostřed širší části s otvorem; E 0586048, N 5539426; hl. $20 \mathrm{~cm}$, ve sterilní půdě těsně pod tmavou povrchovou vrstvou (obr. 14)

277. deformované oko, $51 \times 26 \times 8$ mm; E 0586003, N 5539565; hl. 15 cm v šedém štěrkopísčitém splachu s četnou keramikou (obr. 14)

\section{Zemědělské nářadí}

52. kompletní okutí rýče, $228 \times 151 \times 11$ mm; E 0585950, N 5539489; hl. 8 cm na rozhraní humusové vrstvy a podloží, mírně v podloží (obr. 3) 


\section{Neurčené železné předměty}

66. kus pásoviny, $74 \times 32 \times 7 \mathrm{~mm}$; E 0586018, N 5539496; celková hl. $28 \mathrm{~cm}, 8 \mathrm{~cm}$ humusová vrstva, $16 \mathrm{~cm}$ šedá jílovitopísčitá, $4 \mathrm{~cm}$ v podloží (obr. 15)

68. podlouhlý předmět se zaoblenými konci, $84 \times 32 \times 16$ mm; E 0585956, N 5539474; hl. $10 \mathrm{~cm}$ na rozhraní humusové vrstvy a podloží (obr. 15)

107. hákovitý předmět plošně se na protilehlém konci rozšiřující, $71 \times 50 \times 40 \mathrm{~mm}$; E 0585942 , N 5539484; hl. 13 cm na rozhraní humusové vrstvy a podloží, ca 1,5 m od č. 106 (obr. 14)

115. roztržený kroužek, $53 \times 51 \times 11$ mm; E 0585978, N 5539457; pod hranou cesty, hl. 24 cm, $16 \mathrm{~cm}$ v podložním štěrkopísku (obr. 15)

203. hrotitý předmět, $59 \times 25 \times 17 \mathrm{~mm}$; E 0586007 , N 5539273; hl. $20 \mathrm{~cm}$ na rozhraní podloží a humusové vrstvy (obr. 15)

204. předmět či předměty sestávající z tordované tyčinky a ohnutého pásu, $114 \times 9 \times 9 \mathrm{~mm}$ a $72 \times$ $39 \times 17 \mathrm{~mm}$; E 0586020, N 5539291; hl. $25 \mathrm{~cm}, 5 \mathrm{~cm}$ v podloží (obr. 14)

281. podkovovitý předmět s otvory - podkůvka z boty, $83 \times 11 \times 3 \mathrm{~mm}$; E 0586030 , N 5539333; hl. $20 \mathrm{~cm}, 8 \mathrm{~cm}$ v rezavošedém štěrkopísku (obr. 14)

282. páskové prohnuté kování, $44 \times 40 \times 28 \mathrm{~mm}$; E 0586000, N 5539482; hl. $10 \mathrm{~cm}, 8 \mathrm{~cm}$ v písčité (obr. 14)

284. část silného plátu, $54 \times 35 \times 9 \mathrm{~mm}$; E 0586000 , N 5539485 ; hl. $20 \mathrm{~cm}, 15 \mathrm{~cm}$ v rezavošedém písku (obr. 15)

\section{Předměty z barevných a drahých kovi̊}

28. silně otřelý a rozlomený pražský groš Václava IV., $27,8 \times 28,3 \mathrm{~mm}, 1,91 \mathrm{~g}$; E 0585976 , N 5539439; hl. do ca $15 \mathrm{~cm}$, humusová vrstva, popřípadě rozhraní humusové vrstvy a podloží (obr. 17)

38. zmačkaný plech s otvory ze slitiny mědi, $26 \times 23 \times 5$ mm; E 0585995, N 5539417; hl. $13 \mathrm{~cm}$ při bázi humusové vrstvy (obr. 16)

49. přezka s př́ičnou osičkou a zbytkem trnu ze slitiny mědi, $22 \times 19 \times 3 \mathrm{~mm}$; E 0585963 , N 5539434; hl. 10 cm v jílovitém podloží (obr. 16)

74. čtyři kusy zlomků plechu ze slitiny mědi s přehnutým okrajem s řadou otvorů ca $1,5 \mathrm{~cm}$ od okraje, $57 \mathrm{~mm}, 44 \mathrm{~mm}, 28 \mathrm{~mm}, 14 \mathrm{~mm}$; E 0585977, N 5539443; hl. $16 \mathrm{~cm}, 12 \mathrm{~cm}$ v šedohnědé štěrkopísčité vrstvě (obr. 16)

207. olověný hranolek s otvorem, $26 \times 20 \times 14$ mm; E 0585939 , N 5539574; hl. $8 \mathrm{~cm}$ na rozhraní humusové vrstvy a podloží (obr. 16)

213. přezka sestávající z nezdobeného bronzového kruhového rámečku a železného trnu, $39 \times$ $34 \times 11 \mathrm{~mm}$; E 0586082 , N 5539247; hl. $23 \mathrm{~cm}$, z toho $13 \mathrm{~cm}$ v písčitém podloží, $60 \mathrm{~cm}$ od č. 211 (pata bohatě zdobené bronzové ostruhy, obr. 16)

214. písmem (?) zdobený bronzový kruhový rámeček přezky s odsazením pro trn, $33 \times 32 \times$ 1,5 mm; E 0586068, N 5539278; přístupová šíje, hl. 18 cm, 13 cm ve štěrkopísku (obr. 16, 18:1)

215. nákončí pochvy vyrobené ze stočeného plechu, se zdobeným povrchem, $47 \times 17 \times 11 \mathrm{~mm}$; E 0586062, N 5539361; hl. 20 cm, 16 cm v šedorezavém štěrkopísku (obr. 16)

216. dvoudílná obdélníkovitá přezka, $20 \times 18 \times 2 \mathrm{~mm}$; E 0586049, N 5539258; prŕístupová šíje, hl. $10 \mathrm{~cm}, 5 \mathrm{~cm}$ ve štěrkopísku (obr. 16) 

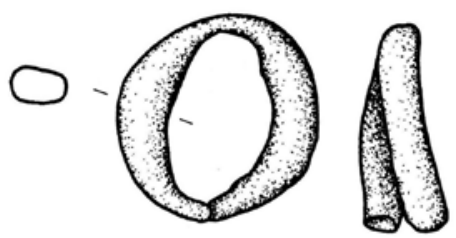

115
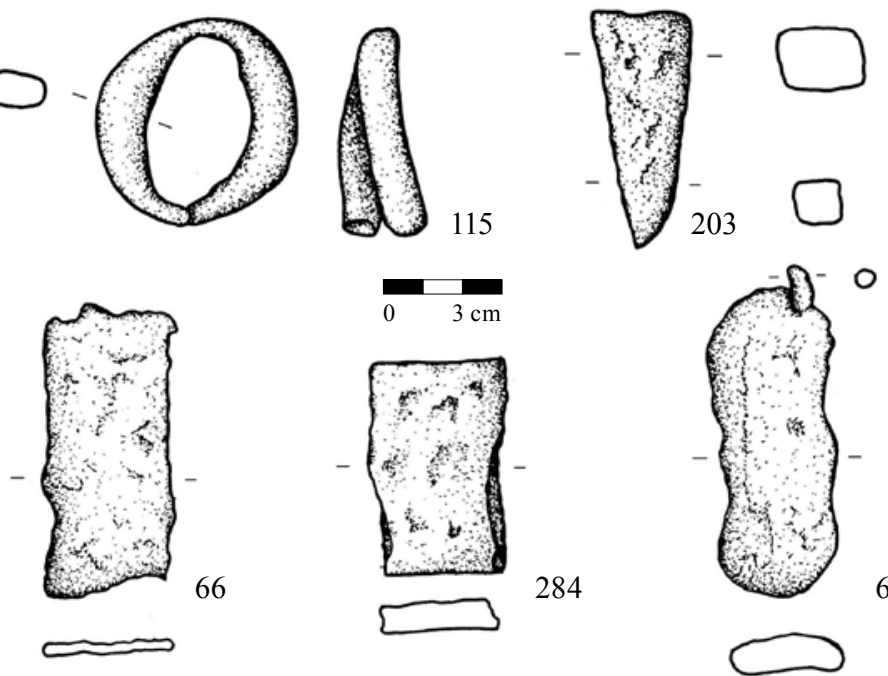

Obr. 15. Železné artefakty z lokality. 115 - článek řetězu, 66, 68, 203, 284 - neurčené předměty. Kresba Tomáš Záruba. Abb. 15. Eisenartefakte von der Fundstätte. 115 - Kettenglied, 66, 68, 203, 284 - unbestimmte Gegenstände. Zeichnung Tomáś Záruba.
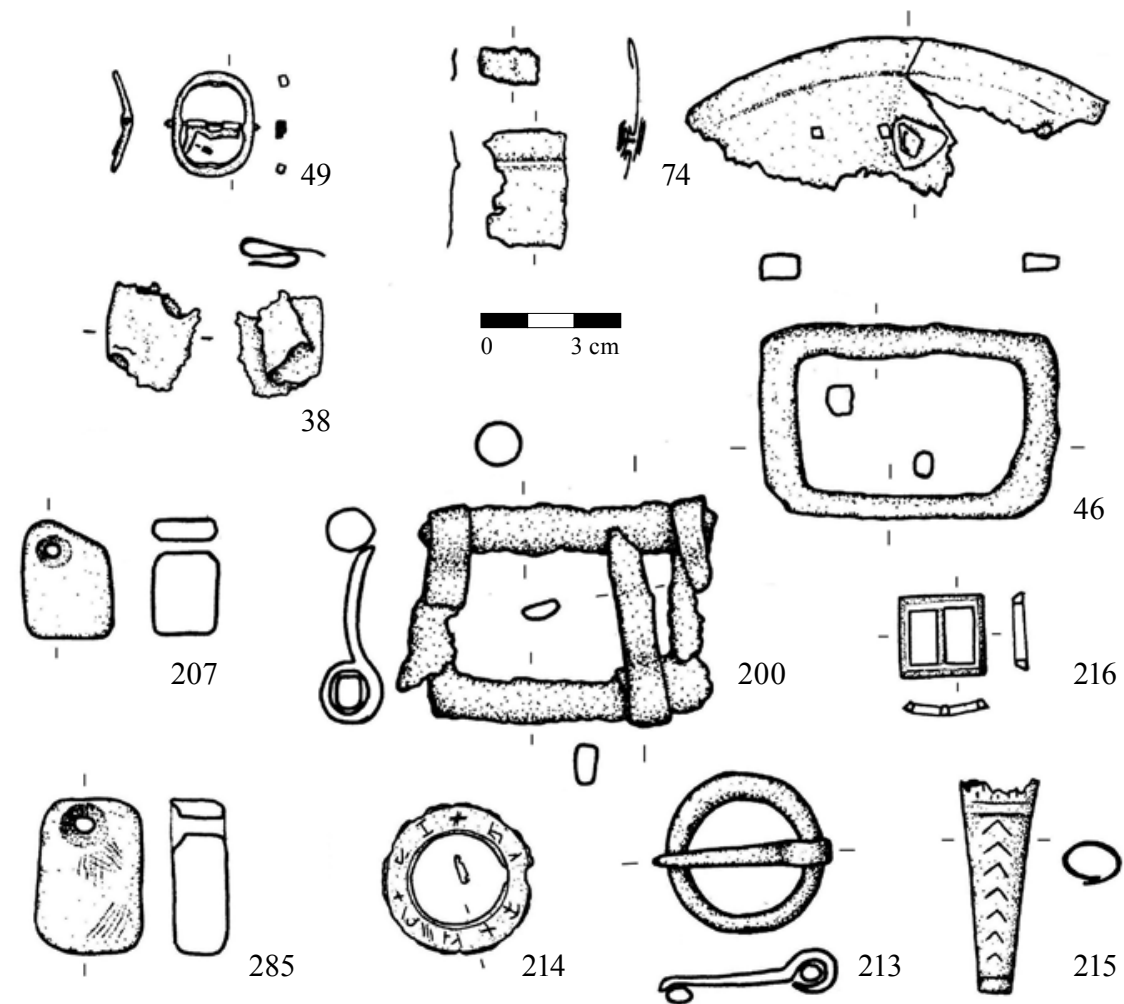

Obr. 16. Železné a neželezné artefakty z lokality. 46, 200 - železo, 38, 49, 74, 213, 214, 215, 216 - slitina mědi, 207, 285 - olovo; 46, 49, 200, 213, 214, 216 - přezky, 38, 74 - plech, 215 - nákončí pochvy, 207, 285 - neurčené. Kresba Tomáš Záruba.

Abb. 16. Eisen- und Metallartefakte von der Fundstätte. 46, 200 - Eisen, 38, 49, 74, 213, 214, 215, 216 - Kupferlegierung, 207, 285 - Blei; 46, 49, 200, 213, 214, 216 - Schnallen, 38, 74 - Blech, 215 - Ortband einer Scheide, 207, 285 - unbestimmt. Zeichnung Tomáš Záruba. 
285. olověný hranolek s otvorem, $34 \times 24 \times 13$ mm; E 0585957, N 5539539; pod lesní hrabankou (obr. 16)

292. drobné liliovité opaskové kování, se dvěma nýtky, 16 × 11 × 2,3 mm; E 0585977, N 5539497; hl. $5 \mathrm{~cm}$ na rozhraní humusové vrstvy a podloží (obr. 18:2)

\section{Vyhodnocení nálezů}

$\mathrm{Z}$ areálu hradu se podařilo získat poměrně reprezentativní kolekci předmětů. Když pomineme již publikované hroty šípů čítající lehce přes dvě stovky kusů (Vích 2017), i tak soubor zbývajících kovových artefaktů přesahuje číslo sto. Nálezy jsou uloženy v Regionálním muzeu ve Vysokém Mýtě, bohužel u mnohých z nich vzhledem k pokročilé korozi zcela chybí kovové jádro. Tento stav jednoznačně zapříčinilo místní převažující štěrkopísčité rychle vysychavé podloží. ${ }^{3} \mathrm{Z}$ tohoto důvodu bude zachování těchto artefaktů pro př́iští generace mimořádně obtížné a u některých je již ted' zřejmé, že nepůjdou zachránit vůbec. ${ }^{4}$

Prostorové vyhodnocení nálezů nepřineslo žádná relevantní zjištění, distribuce nálezů se jeví jako náhodná, bez patrných zákonitostí. Výjimkou je snad jenom obecně nižší počet nálezů na východním svahu k Tiché Orlici. To je ovšem do určité míry nejspíše odrazem zvýšených rabovacích aktivit v daném prostoru, protože tento svah byl s detekční technikou relativně nejsnáze přístupný.

\section{1 Železné předměty}

Když pomineme zmiňované hroty šípů a olověný projektil z palné zbraně, jsou militaria zastoupena na hradě Zítkov poměrně okrajově. Artefakt srdčitého tvaru č. 272 (obr. 3) s odsazeným dříkem představuje záštitný trn tesáku typu $\mathrm{t}_{11}$. $\mathrm{S}$ výskytem těchto záštitných trnů se na základě dosavadních znalostí počítá v průběhu 15.-16. století (Žákovský 2014, 446-447; Žákovský-Schenk 2017, 76).

Druhý zachycený záštitný trn (č. 71, obr. 3) odpovídá typu $\mathrm{t}_{12 \mathrm{a}}$. Datace tohoto typu není zatím příliš ukotvená, $\mathrm{s}$ určitými výhradami danými zatím omezeným počtem dokumentovaných exemplářů se počítá s používáním v 15. až na počátku 16. století. (Žákovský 2014, 448449). Hrotem čepele tesáku nejspíše bude i artefakt č. 3 (obr. 4), bohužel bez možnosti bližší klasifikace.

Pozůstatkem tesáku je pravděpodobně rovněž velmi rozlámané torzo č. 219 (obr. 3) představující zbytek rukojeti s ne zcela bezpečně určitelným tvarem hlavice, která se s výhradami, v důsledku stavu dochování a konzervace, nejvíce blíží typu B (Žákovský 2014, 287-291).

Rovněž artefakt č. 67 (obr. 3) představuje pozůstatek chladné zbraně, konkrétně nákončí pochvy. Ač nálezů tohoto druhu je již dnes známa celá řada, nelze je bohužel jednoznačně blíže datovat, nebot' se v nezměněné formě objevují nejpozději od 12. až do průběhu 16. století (VíchŽákovský 2016, 291, s další literaturou).

V případě kornoutu stočeného z plechu ze slitiny mědi (č. 215, obr. 16) jde s největší pravděpodobností rovněž o jedno z nákončí pochvy, s nimiž se setkáváme u některých typů chladných zbraní (Žákovský 2014, 469-470, s další literaturou). Zejména díky zbytkům zetlelého dřeva zjištěným při vyzvednutí v tuleji můžeme alespoň u tohoto konkrétního předmětu vyloučit souvislost $\mathrm{s}$ opaskem, jak u podobných předmětů předpokládá A. Lungerhausen $(2004,39$, Tafel 6:92). Podobný, ovšem nezdobený předmět pochází z tvrziště v nedalekých Českých Libchavách (Vích 2015a, 173, obr. 9:6).

Podkovy tvoří v souboru poměrně značný podíl a dokládají tak význam koně v životě obyvatel hradu. Všechny jsou vykovány z pásu železa, který se směrem ke středu rozšiřuje,

3 Dle náhodně získané informace však tato skutečnost vedla k tomu, že železné předměty z lokality v důsledku nelegální činnosti mizely o něco pomaleji, protože předměty v tomto stavu nebyly tolik ,sběratelsky“ zajímavé.

4 Již ted' to lze s jistotou říci o zlomcích nožů č. 39, 70, 271, kolečku ostruhy č. 126, torzu ostruhy č. 197 a nejspíše i o nákončí pochvy č. 67. 

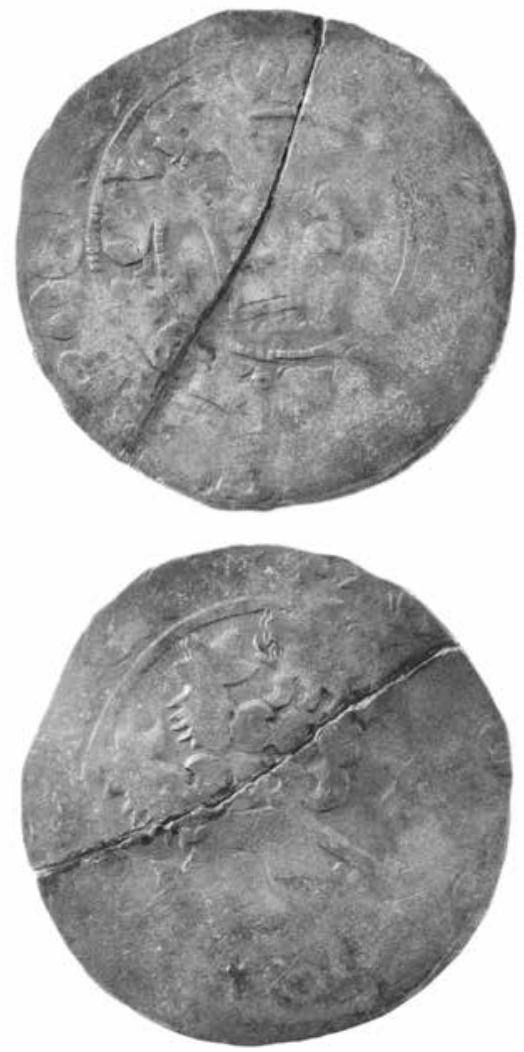

0

$3 \mathrm{~cm}$

Obr. 17. Pražský groš Václava IV.

Abb. 17. Prager Groschen von Wenzel IV.
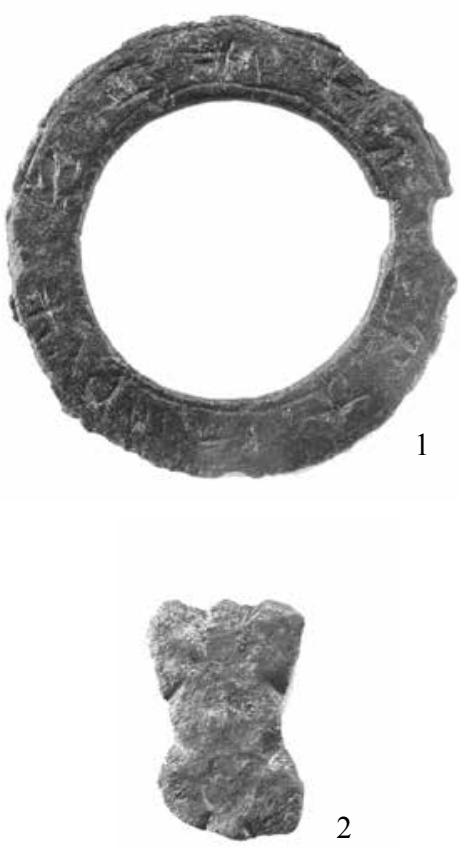

0

$3 \mathrm{~cm}$

Obr. 18. Bronzové artefakty z lokality. 1 - přezka č. 214; 2 - liliovité opaskové kování č. 292

Abb. 18. Bronzeartefakte von der Fundstätte. 1 - Schnalle Nr. 214; 2 - lilienförmiger Gürtelbeschlag Nr. 292

konce ramen nesou ozub, hmatec se neobjevuje ani v jediném případě. I když tyto podkovy lze zařadit do podrobnějších typologických schémat (Kaźmierczyk 1978; Krajíc 2003, 100-109), datování se $\mathrm{u}$ těchto předmětů vzhledem $\mathrm{k}$ absenci hmatce $\mathrm{v}$ zásadě pohybuje $\mathrm{v}$ širším intervalu 13.-15. století.

Z hlediska časového zařazení jsou důležité ostruhy, představují chronologicky relativně citlivé předměty, což ovšem neplatí o dvou dislokovaných kolečkách (č. 76, 126, obr. 10, 11).

Zlomek č. 283 (obr. 11) nese zbytek prohnutého ramena, druhé rameno je odlomeno u samotné paty. V úplnosti se dochoval pouze pyramidovitě ukončený bodec. I když ostruhu nelze pro stav dochování přesněji typologicky klasifikovat, s ostruhami s bodcem a prohnutými rameny se setkáváme ve 12.-13. století (Hilczerówna 1956, 43-63; Ruttkay 1976, 349-350, Abb. 72; Goßler 1998, 546-570).

Ostruhy č. 47 a 209 (obr. 10,11) se vyznačují ostře zalomenými rameny ukončenými asymetricky nasazenými jednoduchými kruhovými úchyty. Vidlice nese kolečka rozdílných velikostí. Tyto ostruhy odpovídají ostruhám typu C podle S. Kołodziejského $(1985,166)$ či IVc/3 podle R. Krajíce (2003, obr. 104) s datací do 13. a 14. století s dozníváním v 15. století (Drobný 
1995, 62-80; Krajíc 2003, 122-125; Koóšová 2004, 533-536, tab. 1). Nejbližší analogie nacházíme ve dvou ostruhách z hradu Orlík u Brandýsa nad Orlicí (Vích-Žákovský 2016, 316, obr. 32:15; 33:39, zde další analogie).

Ostruha č. 122 (obr. 11) s prohnutými rameny ukončenými přibližně obdélnou ploténkou se dvěma horizontálně umístěnými otvory a rameno ostruhy č. 78 (obr. 10) se nejvíce blíží ostruhám typu E podle S. Kołodziejského, který je datuje do průběhu druhé poloviny 14. století $(1985,167)$. Obdobně datuje R. Krajíc (2003, 122-123) svůj typ IVc/2. Rovněž k těmto ostruhám nacházíme řadu analogií datovaných do druhé poloviny 14. století, př́ípadně do staršího úseku 15. století (Slivka 1980, 259; Drobný 1995, 8; Krajíc 2003, 123), což dokládají nálezy z archeologických situací jako například z Chl'aby (Hanuliak 1986, 476, obr. 5), zaniklé Bystřece (Belcredi 2006, 370, tab. XLVI:7-9) či obléhacího opevnění u hradu Lichnice (Frolík 2002, 399, obr. 3:3). Stejně lze datovat i podobnou ostruhu č. 196 (obr. 10) s konci ramen rovněž opatřenými úchyty se dvěma vertikálními otvory, ovšem ploténka je u ní osmičkovitě tvarovaná. Rovněž s tímto prvkem se setkáváme nejčastěji ve druhé polovině 14. až na počátku 15. století (Krajíc 2003, 125). Proti časnějšímu datování (srov. Koóšová 2004, 533-539, tab. 1, 3) hovoří vyvinutá pata (srov. Drobný 1995, 62).

Ostruha č. 197 (obr. 11) má parabolicky prohnutá ramena s krátkou vidlicí. Mohlo by se proto jednat o ostruhu typu III podle Z. Hilczerówny (1956, 63), typu C podle A. Ruttkaye (1976, 350-352) či typu A podle S. Kołodziejského $(1985,165)$ používanou zejména ve 13. a starším úseku 14. století (např. Ruttkay 1976, 352; Slivka 1980, 245-246; Kołodziejski 1985, 165; Koóšová 2004, 530-536), neznáme ovšem tvar úchytů.

Zbývající předměty související s výstrojí koně a jezdce doplňují představu o hradním vybavení, i když jsou (alespoň v tom stavu, v jakém se dochovaly) chronologicky irelevantní. Oválný a přehnutý prredmět č. 275 (obr. 9) představuje nejspíše část třmene, ovšem poněkud nezvykle zhotovenou z relativně tenkého plechu. Jedním kompletním kusem a udítkem (obr. 12) máme doložena stíhlová udidla náležející k typu I (Nadolski 1954, 87), II (Ruttkay 1976, 357-358) či 3 (Krajíc 2003, 112) vyskytujícímu se od pravěku až po novověk. V úplnosti se dochovalo hřeblo s charakteristickou pracovní částí zhotovenou ze železného plechu. Odpovídá typu a podle H. Vogta $(1987,145$, Abb. 115) či druhé skupině podle R. Krajíce $(2003,217)$ s řadou analogií. S používáním vozu souvisí nález zákolníku (č. 114, obr. 12) a zlomek č. 273 představující nejspíše část obruče kola (obr. 14; k problematice středověkého vozu viz Vermouzek 1983). $\mathrm{V}$ publikovaném materiálu se $\mathrm{s}$ analogiemi setkáváme $\mathrm{v}$ různém prostředí, známe je $\mathrm{z}$ hradů Lopata (Novobilský 2008, 96, obr. 110) a Děvín (Polla-Egyházy-Jurovská 1975, 105, 5:3; 18:7), zaniklých vsí Bystřece (Belcredi 2006, 373, tab. XLVII:10-13) a Pfaffenschlagu (Nekuda 1975, 145, obr. 138:1, 3, 5, 6), z Košic (Rusnák 2009, 396, obr. 5:3) a Mstěnic (Nekuda 1985, 127).

Předměty osobní potřeby reprezentují zejména nože, na lokalitě zastoupené 14 kusy, čímž náleží k velmi frekventované skupině nálezů. To není nikterak překvapivé, protože nože patří k základním, a proto nejrozširřenějším nástrojům. Setkáváme se zde s oběma základními konstrukčními řešeními rukojeti, a to jednak s vývojově staršími noži, na něž byla rukojet' naražena pomocí trnu, a jednak s noži s řapem, který nesl nanýtované obložení z organických materiálů. Bohužel obě skupiny patří k průběžným tvarům nepodléhajícím ve vrcholném středověku a starším novověku žádnému vývoji. Podobně jsme na tom i v případě železných přezek č. 46 a 200 (obr. 16). Přezky obecně mohly být využity jako součásti oděvu, případně mohly fixovat řemení zbraní či koňského postroje. V prŕípadě exemplářủ ze Zítkova se vzhledem k jejich velikosti jeví nejpravděpodobnější druhá $\mathrm{z}$ uvedených možností.

Na poněkud jistější půdě se ocitáme v případě uzamykacích mechanismů. V areálu hradu a v jeho bezprostředním okolí se podařilo najít sedm klíčů a tři zámky či jejich části (obr. 13). Otočné klíče č. 199 a 278 s plnými dříky a jednoduchými kruhovými oky patří k typu VI (č. 278), respektive VIII (č. 199) podle R. Krajíce (1991, 332-333, obr. 9; 2003, 92-93, obr. 91). S klíči tohoto typu se setkáváme od raného středověku minimálně do 14. století (Klíma 1980, obr. 41; Slivka 1981, 238-239; Krajíc 1991, obr. 10; 2003). Třetí klíč (obr. 13:202) vykazuje znaky řadící ho k typu X. Zatímco s dutým dříkem se setkáváme již od 13. století (Krajíc 2003, 92-94, obr. 
92; ovšem převládat začíná až později), v kombinaci s malými rozměry, zdobeným okem a složitěji tvarovanou bradou (v našem případě ovšem nedochovanou) jde o podobu vývojově výrazně mladší (srov. Slivka 1981, 239; Belcredi 1988, 464-465; 1989, 454; Brunner 1988, 97-116). Do 15. století je datován klíč se zdobeným okem ze Mstěnic (Nekuda 1985, 158, obr. 212:k) a hradu Sion (Janská 1965, 37, obr. VIII), do 14. století pak klíč s okem rozděleným šesti paprsky z hradu Melice (Unger 1974, 197, obr. 3:15), analogicky je datován i klíč z Rokštejna (Měřínský 2007, 108, obr. 59:9). Do druhé poloviny 14. až do 15. století jsou datovány podobné klíče z Vízmburku (Koštál a kol. 2013, 138). Klíče se zdobenými oky, původně zavěšené zřejmě na jediném opasku, byly nalezeny ve výplni studny ze zánikového horizontu Sezimova Ústí (HrdličkaRichter-Smetánka 1966, 663, 678). Čtyři kliče (č. 4, 65, 198, 217) reprezentují lamelové zásuvné klíče určené pro svorníkové pružinové zámky typu V podle R. Krajíce (2003, 90-91, obr. 92). Tyto klíče se běžně objevují na řadě lokalit s výskytem od 13. do 15. století a těžištěm výskytu ve 14.-15. století, což platí i o třech svorníkových pružinových zámcích a jejich torzech (Merta 1974; Krajíc 1991, 331; 2003, 91). Za stavební kování (když pomineme hojně nacházené hřeby) snad můžeme označit železný hranolovitý předmět s otvorem při okraji č. 2 (obr. 14) K této kategorii můžeme volně připočíst i roztržené oko z řetězu (obr. 15:115), které ale stejně tak může souviset s lesnickými pracemi v nedávné minulosti.

V souboru dosti překvapivě zcela absentují řemeslné nástroje, nástroje zemědělské neméně překvapivě reprezentuje pouze okutí rýče (obr. 3, přičemž zcela postrádáme například jinak zcela běžné zuby z bran, srpy a jejich zlomky apod.). Okutí rýčů a lopat se v prakticky nezměněné podobě objevují od pravěku hluboko do novověku, ve východočeských nálezech (ovšem nejen v nich) se s nimi nesetkáváme př́liš často (naposled Frolík-Musil 2015, 13, s další literaturou).

Poměrně bohatě zastoupenou kategorii představují obtížně určitelné a neurčitelné železné předměty. Relativně nejméně otazníků vyvolává podkovovitý předmět č. 281 (obr. 14) se dvěma otvory. S největší pravděpodobností se jedná o podkůvku z obuvi. V tuzemském prostředí jsou tyto předměty datovány od 16. do 20. století (Cymbalak 2006), přičemž v 16. století se podle všeho objevují poprvé (srov. Slivka 1981, 231; Pilková-Šimončičová-Koóšová 2017, 155). Z ostatních neurčených předmětů stojí za zmínku snad jen předmět č. 282 (obr. 14) s blízkou, byt' možná pouze formální analogií ze Stupavy - Dračího hrádku (Farkaš 2006, obr. 37:6).

\subsection{Předměty z barevných a drahých kovi̊}

Do vrcholného stř̌edověku s jistotou náleží rovněž několik předmětů z neželezných kovů. Z šíje zajišt’ující prrístup na hradní kopec pochází plochá kruhová přezka č. 214 se zeslabením pro trn s (pseudo?) nápisem na lícní straně (obr. 16; 18:1). Stále v zásadě platí poznámka Z. Měřínského (1991, 76-77) o absencích analogií v západoevropském prostředí (srov. Krabath 2001, 131-158), i když teorii o jejich karpatském původu bude zřejmě třeba na základě nových nálezů ověřit. ${ }^{5}$ Těžiště jejich výskytu by mělo ležet ve 13 . až na počátku 14. století s možným pozdějším výskytem (Ruttkay 1989, 363-364; Heindel 1990, 12; Měřínský 1991, 77; srov. též Richter 1982, 185, obr. 132:7; Hanuliak-Nešporová 2001, 334, obr. 6:18).

Další přezka (č. 213, obr. 16) je zhotovena z nezdobeného kruhového rámečku oválného prŕíného průřezu s dochovaným železným trnem a odpovídá formálně typu I podle $\mathrm{K}$. Wachowského $(2001,98)$. Kruhové přezky se obecně vyskytují v dlouhém časovém úseku (Unger a kol. 1980, 49-51), s tvary odpovídajícími studovanému exempláři se setkáváme především ve 13., případně ještě i 14. století (Ruttkay 1989, 362-363; Richterová 1996, 495-496). Do 13. století jsou datovány přezky z brněnského Petrova (Zůbek 2002, 129, 139, 146, obr. 3:5, 7), do druhé poloviny 13. až do 14. století datuje J. Unger analogické přezky ze hřbitova v Tasově (2011, 675). Pouze rámcově do 13.-15. století je možné datovat pár přezek z hrobu H64 z židovského hřbitova ve Vladislavově ulici v Praze (Wallisová 1998, 144, obr. 6; 2002, 87-89, obr. 13).

5 Více nepublikovaných kusů tohoto typu přezek pochází např. z nejnovějších prospekcí z českomoravského pomezí. 
S výskytem dvojdílných pravoúhlých přezek (č. 216, obr. 16) se počítá již od 12. století, přičemž se objevují zejména ve 14. a 15. století (Krabath 2001, 141), přežívají ovšem hluboko do novověku (Marshall 1986, 15; Whitehead 2003, 74-77). Pečlivý způsob zpracování předmětu, subtilnost a koneckonců i častý výskyt na polích v zázemí sídlišt’ stř̌edověkého původu ${ }^{6}$ skutečně ukazuje na rámcové datování do pokročilého vrcholného středověku až staršího novověku, což dokládá nevelké množství bližších i vzdálenějších publikovaných tuzemských analogií (např. Měchurová 1989, tab. II:7; 1997, 131, tab. XLIII:9; Měřínský 2007, obr. 67:15).

Oválná přezka č. 49 (obr. 16) ze slitiny mědi se zbytky jazýčku na osičce již spadá do pokročilého novověku (srov. Whitehead 2003, 96-102) a se životem na hradě nesouvisí.

Subtilní litý bronzový předmět č. 292 (obr. 18:2) se dvěma nýtky představuje silně opotřebené nebo korodované liliovité kování nošené v různých podobách na opascích zejména ve 13. až v počátcích 14. století (Fingerlin 1971, 80, 85; Ruttkay 1989, 367).

Bez možnosti další klasifikace zůstávají útržky plechu ze slitiny mědi (č. 38, 74, obr. 16), olověné artefakty hranolového tvaru (č. 207, 285, obr. 16) představují nejspíše doklady aktivit až po zániku hradu.

\subsection{Keramika}

Významnou část movitých nálezů z lokality tvoří keramika. Když pomineme starší nálezy z Orlického muzea v Chocni (Vích 2009, 14-15), z kolekce uložené v Regionálním muzeu ve Vysokém Mýtě malou část sebrali různí zájemci o historii, část pak sbíral autor, většina pochází ze sběrů žáků ZŠ Svatopluka Čecha v rámci projektové výuky v roce 2010.

Vedle zmiňované a publikované kolekce keramiky z choceňského muzea s počtem lehce přesahujícím číslo 100 pochází z areálu hradu dalších 345 keramických zlomků po slepení. V naprosté většině byla keramika nalezena ve splachových vrstvách na svazích hradního jádra, poměrně reprezentativní vzorek se dostal na povrch v důsledku vývratu dubu na východním svahu spadajícím k Tiché Orlici, ojedinělý střep byl nalezen mimo hradní kopec ve vývratu před prŕstupovou šijí. Několik zlomků (od souboru z akropole se nijak neodlišujících) jsme nalezli na svahu k Tiché Orlici pod předhradím.

V souboru dominuje oxidačně pálená hrnčina různých odstínů červené (189ks, 54,8\%), o něco méně je zastoupeno šedé redukční zboží (107ks, 31,0\%). Bělavá keramika, k níž můžeme připočítat i zlomky s červeným malováním, je zastoupena $28 \mathrm{ks}(8,1 \%)$. Zboží vyrobené v hnědých až šedých odstínech s př́iměsí drcené slídy (tedy co do zpracování keramické hmoty v zásadě ještě v hradištní tradici) se objevuje u 20 zlomků $(5,8 \%)$, jeden okrajový střep nese oboustranně hnědavě žlutou glazuru $(0,3 \%)$. V keramických tvarech jsou vedle dominantních hrncovitých tvarů (někdy s uchy) dále zastoupeny zvonovité pokličky (obr. 20:6, 7, 9, 12-13), mísa (obr. 20:1), džbán (obr. 21:15), trojnožka opatřená hnědožlutou glazurou (obr. 20:10) a pravděpodobně i pohár (obr. 21:20). V technické úpravě povrchu dominuje různě provedená oběžná šroubovice, dále se objevuje vývalková šroubovice. Vedle červeného malování (obr. 19:5; 21:12) se další typy tentokráte vhloubené výzdoby (radélko, obr. 20:2, jednoduchá vlnice, obr. 21:11, 19, promačkávání okraje, obr. 21:8, 14) objevují spíše jen ojediněle.

Vzhledem k absenci pozornosti věnované vrcholně středověké keramice ve východních Čechách a sběrovému původu souboru jsou jeho vypovídací schopnosti omezené. Spokojit se tak musíme s rámcovým datováním do pokročilého 14. až průběhu 15. století, přičemž progresivní prvky závěru 15. století až počátku 16. století zde již nenacházíme (srov. Frolík-Sigl 1990), stejně tak na druhé straně chybí prvky datovatelné do 13. století. Některé typy okruží (obr. 19:2-4, $7 ; 20: 18 ; 21: 11,19)$ a přítomnost archaicky vyhlížející keramické hmoty (ovšem minimálně v jednom případě s aplikovanou vývalkovitou šroubovicí) dovoluje teoreticky uvažovat již o první polovině 14. století (srov. Frolík-Sigl 2002, 62, obr. 4; Vích 2016, 145-146, obr. 14-15).

6 Jde o zkušenost autora vycházející z dlouhodobé prospekce. 

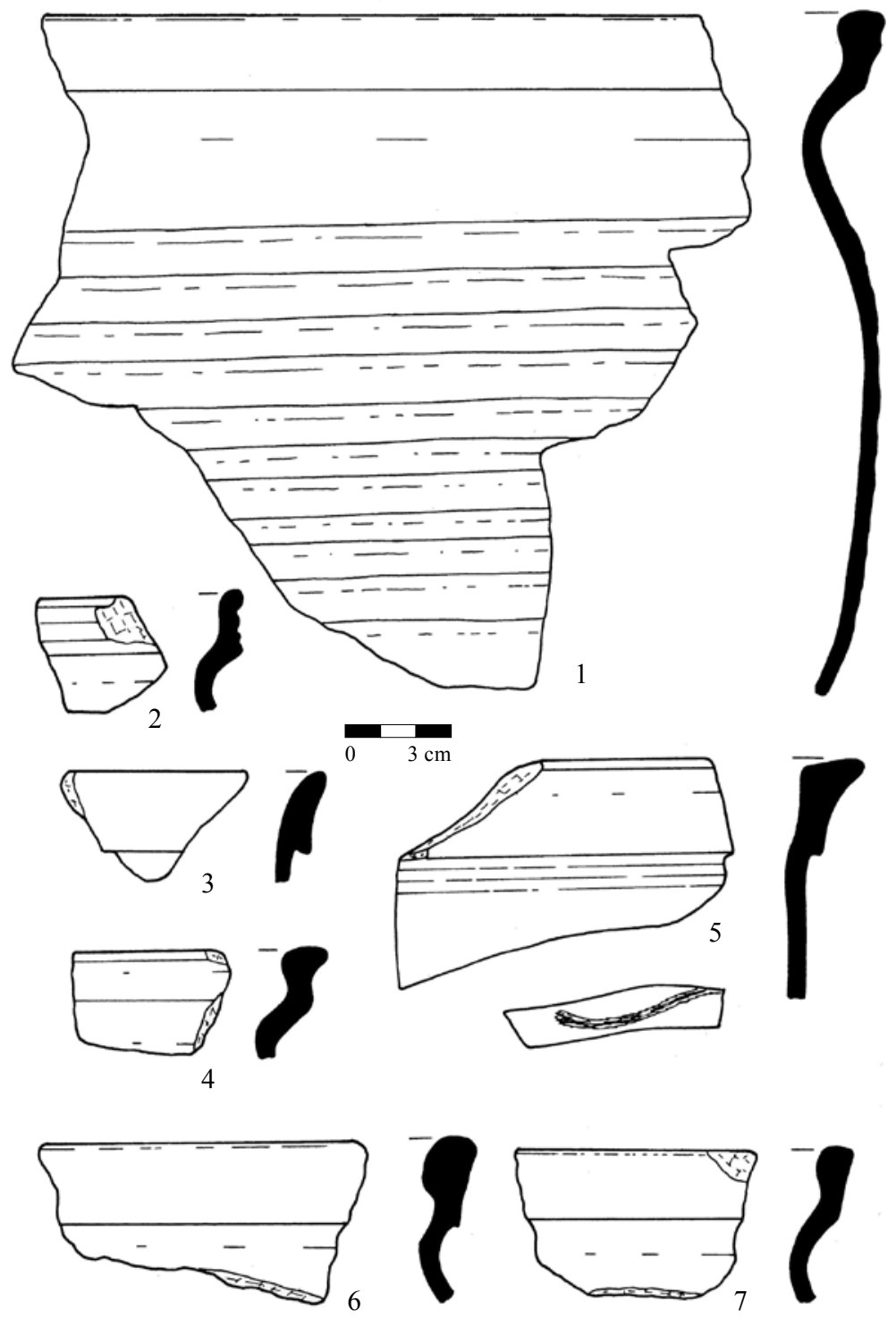

Obr. 19. Keramika z lokality.

Abb. 19. Keramik von der Fundstätte.

\section{Závěr}

Hrad dnes označovaný jako Zítkov žil čistě podle výpovědi archeologických nálezů v pokročilém 14. století a v blíže nespecifikovaném starším úseku 15 . století. Někdy v této době zde zjevně došlo k minimálně jedné vojenské události spojené s dobýváním hradu, což se v archeologických pramenech projevilo kumulací hrotů šípů zejména na hradních svazích, ojediněle se objevuje i olověný válcovitý projektil palné zbraně. Hmotná kultura, prokazatelně již redukovaná 

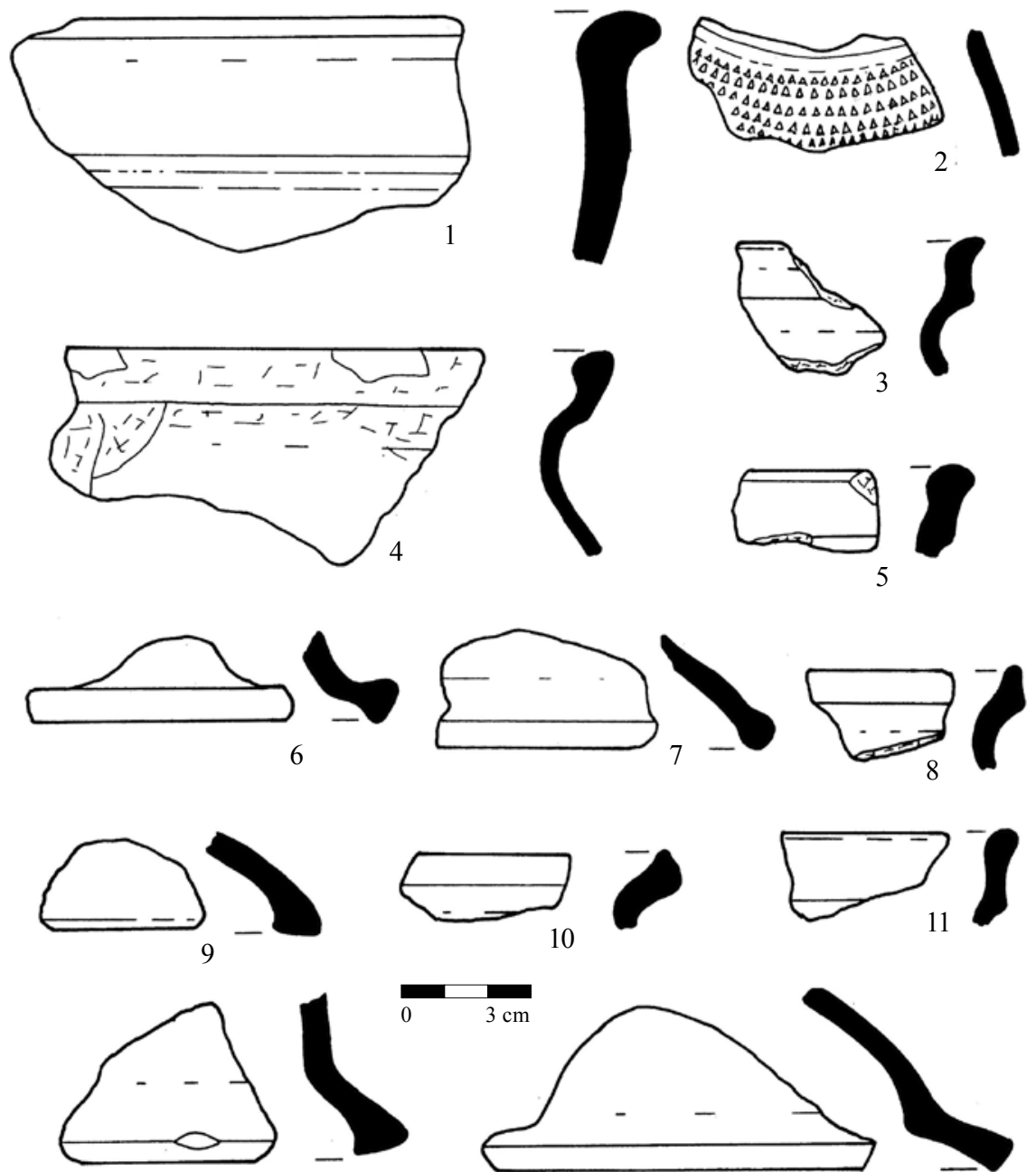

12

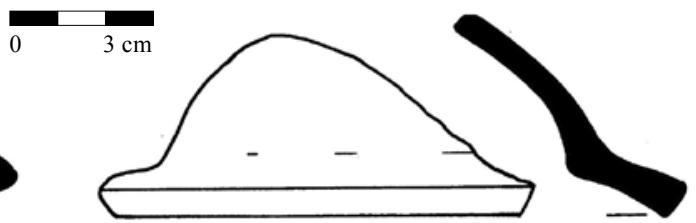

13

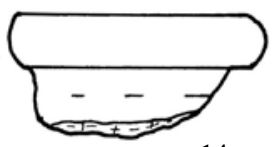

14

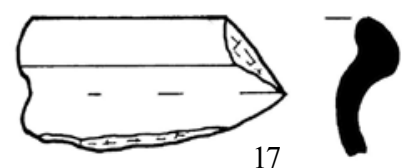

17

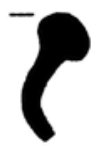

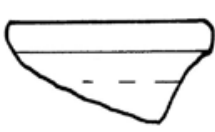

15
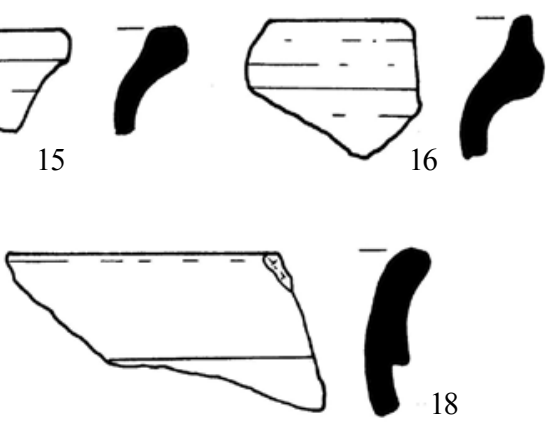

Obr. 20. Keramika z lokality.

Abb. 20. Keramik von der Fundstätte. 

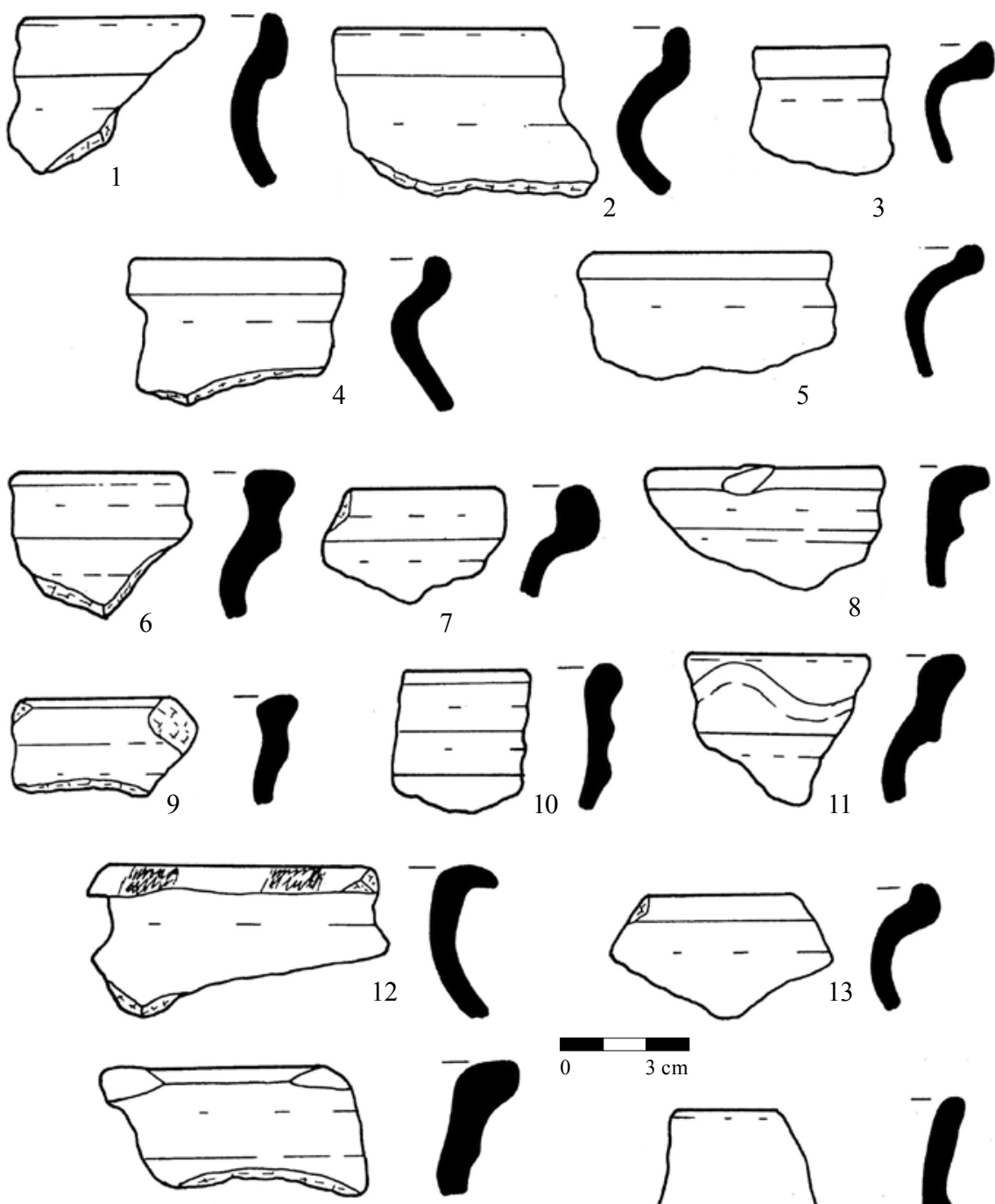

14

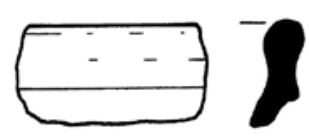

16
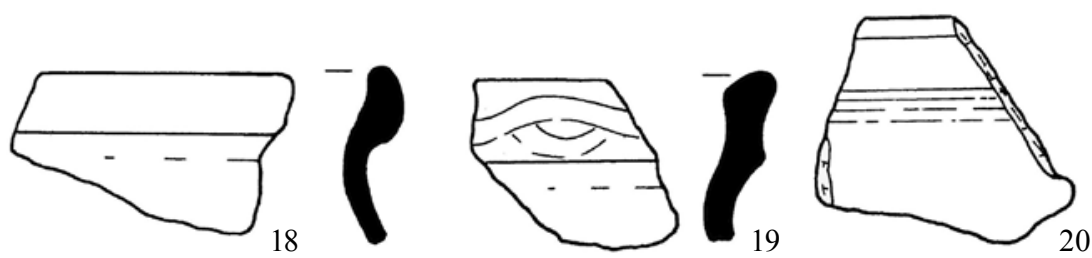

Obr. 21. Keramika z lokality.

Abb. 21. Keramik von der Fundstätte. 
zneužíváním detekční techniky, se v zásadě nijak nevymyká situacím známým odjinud z blízkého či vzdáleného okolí. Překvapit může snad jenom absence (s jedinou výjimkou) zemědělského a řemeslného nářadí a, mimo hrotů šípů, rovněž slabé zastoupení militarií (překvapivé i s ohledem k prokázanému dobývání), což snad lze částečně přičíst na vrub rovněž rabovacím aktivitám na lokalitě. Několik předmětů (torzo železné ostruhy s bodcem, některé předměty z barevných kovů) pak zde zcela nově dokládají starší aktivity. Zatímco torzo ostruhy s bodcem náleží do 12.-13. století, vybrané artefakty z barevných kovů spadají (s větší či menší pravděpodobností) do 13. století až počátku věku následujícího, datování těchto předmětů se tedy protíná ve 13. století, aniž by to nutně dokazovalo jejich současnost. Náhoda nemusí být skutečnost, že takto datované nálezy byly zjištěny zejména na př́istupové šíji do hradního areálu. Pouze liliovité opaskové kování jsme nalezli na severním svahu hradního jádra. Konkretizace aktivit, s nimiž lze tyto relativně archaické nálezy spojit, však zůstává zcela mimo výpovědní možnosti získaných pramenů. Na druhé straně, vzhledem k tomu, že takto datované aktivity nedokládá pouze jediný předmět, musíme počítat s tím, že nejde o náhodný jev.

Před podstatně těžším úkolem stojíme, pokusíme-li se informace získané prostřednictvím archeologických pramenů vztáhnout ke známým pramenům písemným.

S ohledem na datování části souboru se ztotožnění lokality s tzv. Novým hradem, známým z písemných pramenů, jeví jako opodstatněné. Podstatně více otázek vyvolává archeologicky prokázané dobývání hradu. Písemné prameny přímo uvádí jedinou vojenskou událost, jež proběhla na některém z hradů v okolí Chocně, a to již výše zmíněný stručný údaj z roku 1338 o zboření hradu drženého pánem z Potštejna Karlem IV. Toto datování je však v rozporu s archeologickými prameny získanými ze Zítkova. Dispozice Zítkova, většina datovatelných artefaktů a z militarií olověný projektil palné zbraně (bohužel pouze jediný - důsledek rabovacích aktivit?) však přímo či nepřímo ukazují na vojenskou událost, k níž došlo až v pokročilém 14. století či někdy $\mathrm{v}$ počátcích věku následujícího. Ač pro to $\mathrm{v}$ písemných pramenech chybí přímé doklady, nabízí se v této souvislosti události za sporů o dědictví po Zikmundu Pyknovi z Lichtemburka, kdy majetek jako odúmrt' získal král Václav IV., který jej později postoupil Půtovi z Častolovic. To neuznal Boček z Poděbrad, kterému Zikmund Pykna z Lichtemburka učinil nedlouho před svou smrtí dne 3. února 1410 na polovině Chocně a tvrzi zápis na 3000 kop. Dlouho trvající spor vyvrcholil v roce 1433 vypálením Chocně stoupenci Půty z Častolovic (Sedláček 1883, 251). Lze si v této souvislosti dobře představit, že hrad, pokud byl skutečně v držení Bočka z Poděbrad odmítajícího dědictví vydat, se stal rovněž cílem útoku. Na druhé straně několik prokazatelně starších artefaktů získaných z lokality zřetelně signalizuje blíže nespecifikovatelné aktivity někdy v rozmezí 12. až první poloviny 14. století. Podezření dále zesiluje výrazné zastoupení typologicky starších štíhlých hrotů s trnem tvořících navíc koncentrace (Vích 2017, 105) a se značnou mírou opatrnosti snad i některé zlomky keramiky. Teoreticky proto nemůžeme vyloučit, že stávající dvoupalácová dispozice hradu je výsledkem až delšího vývoje s možným starším předchůdcem. Ztotožnění hradu dnes známého jako Zítkov s hradem dobytým Karlem IV. v roce 1338 tak s jistotou vyloučit nemůžeme, zároveň je ale nutné uvést, že by se za stávajícího stavu poznatků jednalo o dosti umělý konstrukt postavený v zásadě pouze na několika jednotlivých nálezech (výraznou přítomnost hrotů s trnem lze vysvětlit i jinak, např́iklad taktickým nasazením luků), a proto není nutné úvahy tímto směrem dále rozvíjet, minimálně do provedení rozsáhlejšího archeologického výzkumu. Nové informace s výrazným historickým přesahem by mohlo přinést vyhodnocení typáře nalezeného na svahu pod hradním jádrem, artefakt je však v privátním držení (Vích 2011, 1006, obr. 8:3).

Každopádně několik století po zániku hradu se jeho zbytky staly svědkem kriminálního činu, kdy zde došlo k uložení části rozstř́haného kalicha nepochybně zcizeného v neznámém kostele. Pár honosných zlacených ostruh nalezený zde v torzu může být rovněž svědectvím kriminálního jednání (Žákovský-Vích 2019), stejně tak ale i dokladem rytířské kultury na lokalitě v dobách její největší slávy. 


\section{Prameny}

BLÁHOVÁ, J. a kol., 1987: Kroniky doby Karla IV. Praha.

CDB II: Codex diplomaticus et epistolaris regni Bohemiae V/1 (Friedrich, G., ed.). Praha 1912.

LOSERTH, J., 1896: Das St. Pauler Formular. Briefe und Urkunden aus der Zeit König Wenzeles II. Gefunden und herausgegeben von Johann Loserth. Prag.

RBM IV: Regesta diplomatica nec non epistolaria Bohemiae et Moraviae IV, 1333-1346 (Emler, J., ed.). Pragae 1892.

\section{Literatura}

BELCREDI, L., 1988: Užití kovu ve středověké osadě. Výsledky dosavadního archeologického výzkumu zaniklé středověké osady Bystřec - Die Verwendung von Metall in mittelalterlichen Siedlungen. Ergebnisse der bisherigen Untersuchungen in der MOW Bystřec, AH 13, 459-485.

- 1989: Terminologie, třídění a kód středověkých kovových předmětů - Terminologie, Klassifizierung und Kode mittelalterlicher metallischer Gegenstände, AH 14, 437-472.

- 2006: Bystř̌ec. O založení, životě a zániku středověké vsi. Archeologický výzkum zaniklé stř̌edověké vsi Bystřece 1975-2005. Brno.

BRUNNER, J.-J., 1988: Der Schlüssel im Wandel der Zeit. Bern - Stuttgart.

CYMBALAK, T., 2006: Wybrane znaleziska podkówek do butów z terenu Czech na tle analogii środkowo-europejskich, Archaeologia Pragensia 18, 263-282.

ČECHURA, M.-VÍCH, D., 2018: Neobvyklé depozitum církevní provenience z hradu Zítkov u Chocně Ein ungewöhnlicher Depotfund kirchlicher Provenienz von Burg Zítkov bei Choceň, AH 43, 411-421.

DURDÍK, T., 2000: Ilustrovaná encyklopedie českých hradů. Praha.

DROBNÝ, T., 1995: Vývoj středověkých ostruh od 11. do počátku 16. století. Magisterská diplomová práce, ulož. v ÚAM FF MU, Brno.

FARKAŠ, Z., 2006: Stredoveké opevnenie v Stupave, poloha Dračí hrádok, ZbSNM C, Archeológia 16, $235-302$.

FINGERLIN, I., 1971: Gürtel des hohen und späten Mittelalters. Berlin.

FROLÍK, J., 2002: Nálezy z obléhání hradu Lichnice v letech 1428-1429, CB 8, 399-408.

FROLÍK, J.-MUSIL, J., 2015: Katalog archeologických nálezů z hradu Košumberka. 1. díl: kovové předměty. Praha - Chrudim.

FROLÍK, J.-SIGL, J., 1990: Soubor pozdně středověké keramiky z Chrudimi - Husovy ulice, Studies in Post-Medieval Archaeology 1, 269-284.

- 2002: K počátkům hradu Košumberka na Chrudimsku - Zu den Anfängen der Burg Kušumberk (Bez. Chrudim), AH 27, 61-77.

GOßLER, N., 1998: Untersuchungen zur Formenkunde und Chronologie mittelalterlicher Stachelsporen in Deutschland (10.-14. Jahrhundert), Bericht der Römisch-germanischen Kommission 79, 479-664.

HANULIAK, M., 1986: K stavebno-funkčnej interpretácii obytného objektu z Chlaby - Zur funktionellen Interpretation eines Wohnobjektes aus Chlaba, AH 11, 469-478.

HANULIAK, M.-NEŠPOROVÁ, T., 2001: Rekonštrukcia stredovekého osídlenia v Skalke nad Váhom Rekonstruktion der mittelalterlichen Besiedlung in Skalka a. d. Váh, AH 26, 325-342.

HEINDEL, I., 1990: Riemen- und Gürtelteile im westslawischen Siedlungsgebiet. Berlin.

HILCZERÓWNA, Z., 1956: Ostrogi polskie z X-XIII wieku. Poznań.

HRDLIČKA, L.-RICHTER, M.-SMETÁNKA, Z., 1966: Výzkum v Sezimově Ústí v r. 1965, AR XVIII, $663-680$.

JANSKÁ, E., 1965: Hrad Jana Roháče z Dubé, Sión. In: Sborník Oblastního muzea v Kutné Hoře, řada A historická, 5-72. Kutná Hora.

KAŹMIERCZYK, J., 1978: Podkowy na Śląsku w X-XIV wieku. Studia z dziejów kultury materialnej. Prace Komisji Nauk Humanistycznych Nr. 9. Wrocław - Warszawa - Kraków - Gdańsk.

KLÍMA, B., 1980: Zámečnická práce staromoravských kovářủ v Mikulčicích. Praha.

KOŁODZIEJSKI, S., 1985: Les éperons a molette du territoire de la Petite Pologne au Moyen Âge. In: Mémoires Archéologiques (Kokowski, A., ed.), 161-179. Lublin.

KOÓŠOVÁ, P., 2004: Ku klasifikácii vrcholnostredovekých ostrôh z územia Slovenska (12.-15. storočie) Zur Klassifikation der hochnmittelalterlichen Sporen auf dem Gebiet der Slowakei (12.-15. Jahrhundert), AH 29, 523-547.

KOŠŤÁL, J. a kol., 2013: Vízmburk. Př́iběh ztraceného hradu. Havlovice. 
KRABATH, S., 2001: Die hoch- und spätmittelalterlichen Buntmetallfunde nördlich der Alpen. Eine archäologisch-kunsthistorische Untersuchung zu ihrer Herstellungstechnik, funktionalen und zeitlichen Bestimmung. Rahden/Westf.

KRAJÍC, R., 1991: Stavební železo a uzavírací mechanismy na vrcholně středověkých lokalitách Táborska - Eiserne Baubeschläge und Verschliessungsmechanismen von den hochmittelalterlichen Lokalitäten in der Gegend von Tábor, AH 16, 323-344.

- 2003: Sezimovo Ústí. Archeologie středověkého poddanského města 3. Kovárna v Sezimově Ústí a analýza výrobků ze železa. Díl I. Praha - Sezimovo Ústí - Tábor.

LUNGERHAUSEN, A., 2004: Buntmetallfunde und Hnadwerksrelikte des Mittelalters und der frühen Neuzeit aus archäologischen Untersuchungen in Braunschweig. Rahden/Westf.

MARSHALL, Ch., 1986: Buckles Through the Ages. Essex.

MĚCHUROVÁ, Z., 1989: Nálezy bronzových předmětů ze zaniklé středověké osady Konůvky (okr. Vyškov) - Funde bronzener Beschläge in der mittelalterlichen Wüstung Kkonůvky (Bez. Vyškov), AH 14, 473-488.

- 1997: Konůvky - zaniklá středověká ves ve Ždánickém lese. Praha.

MERTA, J., 1974: Nález válečkovitého zámku a klíče na středověké fortifikaci pod Novým hradem, VVM XXVI, 165-169.

MĚŘÍNSKÝ, Z., 1991: K chronologickému postavení přezek se zdobeným kruhovým rámečkem a zeslabením v místě uchycení očka trnu. In: Sborník Společnosti přátel starožitností 2, 75-78. Praha.

- 2007: Hrad Rokštejn. Dějiny, stavební vývoj a výsledky čtvrtstoletí archeologického výzkumu 19812006. Brtnice - Brno.

MUSIL, F., 1995: Hrady, tvrze a zámky okresu Ústí na Orlicí. Ústí nad Orlicí.

NADOLSKI, A., 1954: Studia nad uzbrojeniem polskim w X, XI i XII wieku. Łódź.

NEKUDA, V., 1975: Pfaffenschlag. Zaniklá středověká ves u Slavonic. Brno.

- 1985: Mstěnice. Zaniklá středověká ves 1 . Hrádek - tvrz - dvůr - předsunutá opevnění. Brno.

NOVOBILSKÝ, M., 2008: Obléhání hradu Lopata. Rekonstrukce obléhání hradu z roku 1432-1433. Plzeň.

PILKOVÁ, L.-ŠIMONČIČOVÁ-KOÓŠOVÁ, P., 2017: Predmety každodennej potřeby z Čeboviec - Zeleného hradu (okr. Vel'ký Krtíš) - Gegenstände des alltäglichen Bedarfs aus Čebovce - Zelený hrad (Bez. Vel'ký Krtíš), ZbSNM CXI, Archeológia 27, 153-161.

POLLA, B.-EGYHÁZY-JUROVSKÁ, B., 1975: Stredoveké pamiatky hmotnej kultúry z archeologických výskumov na Devínskom hrade, ZbSNM LXIX, 97-168.

RICHTER, M., 1982: Hradišt'ko u Davle. Městečko ostrovského kláštera. Praha.

RICHTEROVÁ, J., 1996: Kruhové přezky z výzkumu na Jungmannově náměstí v Praze - Ringförmige Schnallen aus der Forschung auf dem Jungmannsplatz in Prag, AH 21, 493-498.

RUSNÁK, R., 2009: Novšie nálezy stredovekých kovových predmetov z Košic - Die neuesten Funde mittelalterlicher Metallgegenstände aus Košice, AH 34, 393-407.

RUTTKAY, A., 1976: Waffen und Reiterausrüstung des 9. bis zur ersten Hälfte des 14. Jahrhunderts in der Slowakei (II), SlArch XXIV, 245-395.

- 1989: Prvky gotickej módy v odeve a ozdobách dedinského obyvatel'stva na území Slovenska (Horizont hrobov zo 14.-15. stor. v Ducovom, obec Moravany nad Váhom) - Elemente der gotischen Mode in Kleidung und Schmuck bei der ländlichen Bevölkerung auf dem Gebiet der Slowakei (Grabhorizont aus dem 14.-15. Jh. in Ducové, Gemeinde Moravany nad Váhom), AH 14, 355-378.

SEDLÁČEK, A., 1883: Hrady, zámky a tvrze království českého II. Hradecko. Praha.

SLIVKA, M., 1980: Stredoveké hutníctvo a kováčstvo na východnom Slovensku. 2. čast’, Historica Carpatica XI, 218-288.

- 1981: Stredoveké hutníctvo a kováčstvo na východnom Slovensku. 3. čast', Historica Carpatica XII, 211-276.

UNGER, J., 1974: Archeologické nálezy z výzkumu hradu Melic na Vyškovsku (železné předměty), VVM XXVI, 194-201.

- 2011: Přezky s kruhovým rámečkem jako součást mužského oděvu ve středověku - Round clasps as part of men's attire in the Middle Ages, AR LXIII, 644-665.

UNGER, J. a kol., 1980: Pohořelice-Klášterka. Praha.

VERMOUZEK, R., 1983: Středověký vůz - Der Wagen im Mittelalter, AH 8, 311-325.

VÍCH, D., 2009: Orlické muzeum v Chocni. Katalog archeologické sbírky I. Zprávy České archeologické společnosti - Supplément 74. Praha.

- 2011: Archeologické nálezy z jedné privátní sbírky, ASČ 15, 999-1015.

- 2015: Př́ispěvek k metodice detektorové prospekce v archeologii - A contribution to the methodology of metal detector prospecting in archaeology, AVČ 7 (2014), 152-172. 
- 2015a: Př́íspěvek k poznání tvrziště v Českých Libchavách na Orlickoústecku - Ein Beitrag zu den Erkenntnissen über die Festungsstätte in České Libchavy im Bezirk Ústí nad Orlicí, AH 40, 163-177.

- 2016: Hrádek v Hrádníkách u Zářecké Lhoty na Choceňsku - Eine Burg in Hrádníky bei Zářecká Lhota in der Region Choceň, AH 41, 143-166.

- 2017: Projectile head finds from Zítkov Castle near Choceň, Acta Militaria Mediaevalia XIII, 83-109.

VÍCH, D.-ŽÁKOVSKÝ, P., 2016: Vojenské vybavení bojové družiny před husitskou revolucí. Soubor militárií z hradu Orlík u Brandýsa nad Orlicí ve východních Čechách, PA CVII, 279-351.

VOGT, H.-J., 1987: Die Wiprechtsburg Groitzsch. Eine mittelalterliche Befestigung in Westsachsen. Berlin.

WACHOWSKI, K., 2001: Spätmittelalterliche Gürtel des Adels in Schlesien im Lichte archäologischer Quellen, Zeitschrift für Archäologie des Mittelalters 29, 87-112.

WALLISOVÁ, M., 1998: První etapa výzkumu židovského hřbitova na Novém Městě pražském. Předběžná zpráva - Die erste Etappe der Ausgrabung auf dem jüdischen Friedhof in der Prager Altstadt. Ein Vorbericht, Archaeologica Pragensia 14, 141-148.

- 2002: Předběžná zpráva o záchranném archeologickém výzkumu v letech 1997-2000 na židovském hřbitově ve Vladislavově ulici na Novém Městě pražském - A preliminary report on rescue excavations conducted in 1997-2000 at the jewish cemetery in Vladislavova ul. in the Prague New Town, Archaeologica Pragensia 16, 73-98.

WHITEHEAD, R., 2003: Buckles 1250-1800. Essex.

ZŮBEK, A., 2002: Středověké přezky v brněnských nálezech - Medieval buckles from excavations of Brno, SPFFBU M 7, 123-153.

ŽÁKOVSKÝ, P., 2014: Tesáky a problematika jednosečných zbraní středověku a raného novověku. Nepublikovaná disertační práce, ulož. v ÚAM FF MU, Brno.

ŽÁKOVSKÝ, P.-KOŠTA, J.-HOŠEK, J., v tisku: Medieval and early renaissance swords from the Czech lands in the European context. Part I. The 9th to mid-16th century finds from the territory of the Czech Republic.

ŽÁKOVSKÝ, P.-SCHENK, Z., 2017: Středověké a raně novověké zbraně Přerovska. Zbraně a zbroj od kolapsu Velké Moravy do konce třicetileté války. Přerov - Brno.

ŽÁKOVSKÝ, P.-VÍCH, D., 2019: Pár zlacených ostruh od hradu Zítkova u Chocně ve východních Čechách, AR LXXI, 82-104.

\section{Zusammenfassung}

\section{Die Burg Zítkov bei Choceň im Lichte der archäologischen Funde}

Die Gewinnung von Erkenntnissen über die hochmittelalterliche Befestigung in der Umgebung von Choceň zählt wegen der Inkongruenz der schriftlichen und materiellen Quellen zu den sehr schwierigen Aufgaben. Die erste, allerdings leider sehr unklare Erwähnung der Burg in Choceň hängt mit dem Ende des 13. Jahrhunderts zusammen. Aufgrund Berichten aus dem 14. Jahrhundert pflegt man die Burg heute nach den neuzeitlichen Besitzern der Ländereien als Burg Zítkov zu bezeichnen, die mit der im Jahr 1388 erwähnten Nový Hrad (Neue Burg) identifiziert wird.

In einer Entfernung von $1650 \mathrm{~m}$ westlich vom Stadtzentrum Choceň befinden sich auf einem Berg oberhalb der Stillen Adler in einer Höhe von ca. $330 \mathrm{~m}$ über dem Meeresspiegel die Überreste einer Burg (Abb. 1). Der Burgkern wird durch eine Anhöhe gebildet, die von Westen her von einem Abhang abgegrenzt wird, der zu einem namenlosen kleinen Wasserlauf hin abfällt und zwei in den Hang eingeschnittene Plateaus aufweist. Der Nordhang wird dann durch einen Wall und einen Graben geschützt, im Süden fällt das Gelände dann zur Stillen Adler hin ab. Im Süden wird der Burgkern von der Vorburg durch einen Graben getrennt. Der mehr oder weniger ebene Burgkern wird durch zwei Senken gegliedert, welche die Überreste des Souterrains zweier Bauten darstellen. Die Vorburg ist ebenfalls eben und wird vom Vorfeld durch einen Graben abgetrennt. Noch weiter südlich ist im Gelände der Überrest eines weiteren Grabens zu erkennen, wobei die Anhöhe in diesem Teil in westlicher Richtung durch einen als Zugang dienenden Geländerücken mit dem umliegenden Gelände verbunden ist (Abb. 2). Dort ist bisher keine archäologische Grabung erfolgt. Hinsichtlich dessen, dass die Fundstätte Ziel illegaler 
Aktivitäten seitens Benutzern von Metalldetektoren wurde, hat man an der Fundstätte unter der Regie des Regionalmuseums in Vysoké Mýto in den Jahren 2007-2011 eine Detektoruntersuchung durchgeführt.

An der Fundstätte konnten über dreihundert Artefakte gefunden werden, wobei die Pfeilspitzen und Schusswaffenprojektile (über zweihundert Gegenstände) bereits veröffentlicht wurden.

In der Kollektion sind auch Militaria vertreten (Jagdmesser und Jagdmesserteile, Abb. 3:71, 272, 219, Abb. 4:3; Ortband einer Schwertscheide, Abb. 3:67), Reiter- und Pferdeausrüstung (Hufeisen, Abb. 5-8; 9:55-57, 224, 289, 290; Steigbügel, Abb. 9:275; Sporen, Abb. 10-11; Striegel, Abb. 12:193; Zaumzeug, Abb. 12:274, 276), Schlösser und Schlüssel (Abb. 13), Wagenbestandteile (Radnagel, Abb. 12:114; Fragment eines Radreifs, Abb. 14:273), Gegenstände des persönlichen Bedarfs (Messer, Abb. 3:39, 85, 86; 4:1, 9, 10, 43, 70, 125, 194, 195, 218, 279; Schnallen, Abb. 16:46, 200, 213, 214, 216; Schuhsohlenbeschlag, Abb. 14:281; Gürtelbeschlag, Abb. 18:2), eine Reihe von Gegenständen bleibt unbestimmt. Münzen werden durch einen Prager Groschen von Wenzel IV. repräsentiert (Abb. 17). Nur einige Gegenstände fallen in die Zeit des 13. bis zum Beginn des 14. Jahrhunderts (Abb. 11:283; 16:213, 214; Abb. 18:2), der Schwerpunkt des Fundspektrums liegt im Bereich des fortgeschrittenen 14. bis zur älteren Phase des 15. Jahrhunderts, was (mit Ausnahme des 13. Jahrhunderts) von den Keramikfunden bestätigt wird (Abb. 19-21).

Anhand der Funde können wir einen Besiedelungsschwerpunkt im fortgeschrittenen 14. Jahrhundert bis zur älteren Phase des 15. Jahrhunderts feststellen. Deshalb erscheint eine Identifizierung mit der aus den schriftlichen Quellen bekannten Burg Nový Hrad als begründet. Ferner kam es dort irgendwann in diesem Zeitraum zu mit der Einnahme der Burg verbundenen militärischen Ereignissen, was in den archäologischen Quellen als gehäuftes Vorkommen von Pfeilspitzen an den Burghängen in Erscheinung trat. Eine Konkretisierung dieser Ereignisse anhand der Aussagen der schriftlichen Quellen ist jedoch sehr schwierig. Höchstwahrscheinlich sind diese Funde ein Beleg für die Streitigkeiten um das Erbe des 1410 verstorbenen Siegmund Pykna von Lichtenburg, wobei die Streitigkeiten darin gipfelten, dass Choceň im Jahr 1433 niedergebrannt wurde. Im Hinblick auf mehrere in das 13. bzw. an den Anfang des 14. Jahrhunderts datierte Gegenstände können wir auch die Möglichkeit nicht ausschließen, dass die bestehende Anlage der Burg mit zwei Palasbauten gar das Ergebnis einer längeren Entwicklung mit einer möglichen älteren Vorgängerburg ist. Diese Möglichkeit ist bei dem derzeitigen Kenntnisstand jedoch nur Theorie.

PhDr. David Vích, Regionální muzeum ve Vysokém Mýtě, Šemberova 125, 56601 Vysoké Mýto, Česká republika,dvich@centrum.cz 
